\title{
Füze Tehdidi ve NATO Füze Kalkanı: Türkiye Açısından Bir Değerlendirme
}

\author{
S1tk1 EGELI*
}

\section{ÖZET}

ABD ve NATO'nun son yıllarda üzerine önem ve öncelikle eğildiği füze savunma kalkanının temelinde, İran'ın nükleer silah edinme emellerinin doğrudan bir uzantısı olarak değerlendirilen İran'ın balistik füze envanterinden duyulan kaygılar ve tehdit algılamaları yatmaktadır. ABD'nin 2010 y1lında gündeme getirdiği ve NATO ülkeleri nezdinde kabul gören EPAA (European Phased Adaptive Approach) adlı füze savunma yaklaşımı, Türkiye'nin füze tehdidi karşısındaki geleneksel yaklaşımlarıyla uyumlu olduğundan Ankara tarafindan da benimsenmiş ve Türkiye EPAA için kritik önemde bir ülke konumuna yükselmiştir. Diğer taraftan, aslında ABD'nin tahsis ettiği askeri ve teknolojik kaynaklar üzerine inşa edilen EPAA yapılanmasında, NATO'nun Avrupalı müttefiklerinin katkıları ve olası bir çatı̧̧manın seyri üzerindeki kontrolleri sınırlı düzeyde kaldığı gibi, EPAA'ya yönelik olarak önemli bazı teknolojik, operasyonel, takvimsel ve siyasi/stratejik belirsizlikler mevcuttur. Diğer taraftan, EPAA'nın ilerleyen safhalarında Türkiye'nin yeni bazı talep ve oldu-bittilerle karşı karşıya kalabileceği ihtimali göz ardı edilmemeli, bu olasılıkların Rusya ile ilişkiler ve Batı ile ilişkilerde ABD-Avrupa dengesinin gözetilmesi gibi farklı açılardan hesaba katılması gerekmektedir.

Anahtar Sözcükler: Balistik Füzeler; Füze Savunması; Kitle İmha Silahları; Caydırıcılık (Strateji); NATO.

\section{Ballistic Missile Threat and NATO's Missile Defense Shield: An Analysis from Turkey's Perspective}

\begin{abstract}
Concerns emanating from the inexorable link between Iran's growing ballistic missile inventory and it ambitions to acquire nuclear weapons capability are at the heart of recent US and NATO efforts to constitute a ballistic missile defense shield. EPAA (European Phased Adaptive Approach) pushed on the table by US in 2010 and endorsed by most NATO states is in harmony with Turkey's traditional positioning in the face of missile threat. Thence, not only Turkey has endorsed EPAA, but it has also become a pivotal ally in its implementation. Additionally, handing over the task of missile defense to NATO and US would enable Turkey to allocate its limited defense funds elsewhere. On the negative side, during the upcoming phases of EPAA Turkey should not underestimate the possibility of new requests and even fait-accomplis imposed upon herself, and Ankara should carefully consider possible ramifications of those on her relations with Russia, as well as her traditional policy line of observing a balance between US and European elements of her overall relationship with the West.
\end{abstract}

Keywords: Ballistic Missiles, Ballistic Missile Defenses, Weapons of Mass Destruction, eterrence (Strategy), North Atlantic Treaty Organization.

* Dr. Sitkı Egeli, Ankara. E-posta: sitki@mezun.bilkent.edu.tr. Bu makale, yazarın İstanbul Bilgi Üniversitesi Yayınevi tarafindan Mustafa Aydın'ın editörlüğünde hazırlanan Güvenlik Çalışmaları Serisi'nin ikinci kitabı olan Füze Tehdidi ve NATO Füze Kalkanı: Türkiye Açısından Bir Değerlendirme, (İstanbul: İstanbul Bilgi Üniversitesi Yayınları, No.404, Aralık 2012.) başlıklı kitabı esas alınarak hazırlanmıştır. 


\section{Giriş}

Soğuk Savaş yıllarında Doğu ile Batı blokları arasındaki nükleer dehşet dengesinin ana unsurlarından birisini oluşturan, 1970'li yıllardan itibaren Türkiye'nin komşularının envanterine de girmeye başlayan balistik füzelerin Türk kamuoyunun gündemine gelmesi ve Türkiye'nin tehdit algılamaları arasında kendine yer bulması 1991 Körfez Savaşı sırasında olmuş, Irak'ın Scud ve türevi balistik füzelerine karşı Türkiye'nin kendini koruyacak imkânlara sahip olmadığının fark edilmesi kaygı ve şaşkınlık yaratmıştır. ${ }^{1}$ Irak'ın mağlup olması ve tehlikenin geçmesinden sonra bu konudaki farkındalık ve kaygılar unutulmuş, konu 2003'de kadar Türk kamuoyunun gündeminde kendine yer bulamamıştır.

2003'de Amerika Birleşik Devletleri'nin Irak’a yönelik işgal harekâtı sırasında Saddam Hüseyin rejiminin denetimlerden kaçırarak bir kenara saklamış olabileceği balistik füzelerle komşu ülkelere intikam saldırılarında bulunabileceği iddiaları ve bazı Kuzey Atlantik İttifakı Örgütü (North Atlantic Treaty Organization - NATO) üyelerinin bu türden bir tehdidi bertaraf etmek için Doğu Anadolu'ya Patriot hava savunma sistemleri konuşlandırması konusunda gösterdiği isteksizlik, Türk kamuoyunun ve siyasi mercilerinin dikkatini tekrar füze tehdidi üzerinde yoğunlaştırmıştır. ${ }^{2}$ 1991'deki Körfez Savaşı'nın üzerinden 12 yıl geçmiş olmasına karşın henüz kazanılmamış füze savunma yeteneklerinin süratle ve birinci öncelikle tesis edileceği yönünde açıklamalar yapılmıştır. ${ }^{3}$

$\mathrm{Bu}$ yönde somut bir adım atılmamış, 8 yıl aradan sonra konunun başka bir boyutuyla tekrar gündeme gelmesi için NATO'nun Kasım 2010'daki Lizbon Zirvesi'nin beklenmesi gerekmiştir. Lizbon Zirvesi’nde Türkiye, İttifak’a yönelik balistik füze tehdidinin birincil ve öncelikli kaynağı olarak İran'ın adının açık bir şekilde zikredilmesine karşı çıkarak gerek yurtiçi gerekse uluslararası kamuoyunda tartışma yaratmıştır. ${ }^{4}$ Lizbon Zirvesi'nden sadece 9 ay sonra bu kez de, İran'dan firlatılacak balistik füzelere yönelik

1 “Gökte Füze Savaşı, Yerde Panik”, Milliyet, 22 Ocak 1991; "Scud'un panzehiri Patriot”, Milliyet, 19 Ocak 1991; Hakkı Arıs, "Türkiye'nin Hava avunması: Genel Bir Bakış", Savunma ve Havacılı, 1/1992, s. 52.

2 "Germany reluctant to defend Turkey if Iraq retaliates", Washington Post, 22 Ocak 1991, p. A20; Süleyman Mermut, "Türkiye'nin Patriot açmazı", NTVMSNBC, 6 Şubat 2003, http:// arsiv.ntvmsnbc.com/news/200570.asp (Erişim Tarihi: 13 Nisan 2012); Güldener Sonumut, "NATO'da güven bunalımı", NTVMSNBC, 7 Şubat 2003, http://arsiv.ntvmsnbc.com/ news/200850.asp (Erişim Tarihi: 10 Nisan 2012); "Deadlock Broken, NATO to Defend Turkey”, CBS Nerws, 17 Şubat 2003, http://www.cbsnews.com/stories/2003/02/17/iraq/ main540829.shtml (Erişim Tarihi: 14 Nisan 2012).

3 “200 Patriot için görüşme sürüyor”, Milliyet, 9 Mart 2003; Hava Kuvvetleri Komutanlığ 1 , "TSK'nde Hava ve Füze Savunması Konusundaki Gelişmeler ve Geleceğe Yönelik Hedefler", Savunma E Havacılık, 2003/97, s. 48-54; "Amerikan-Türk Konseyi 2003 Toplantıs1 (ATC-03)", Savunma ve Havacılık, 2003/95, s. 43; Lale Sariibrahimoğlu, "Ankara clears missile defence purchase”, Jane's Defence Weekly, 3 Mayıs 2006, s. 14.

4 “Karar yok, NATO'nun adımları izlenecek", Radikal, 13 Kasım 2010; “Kalkana Türk-Fransız çelmesi”, Radikal, 15 Ekim 2010; Deniz Eyrek, "ABD ile kılıç kalkan dansı”, Radikal, 14 Ekim 2010; Ümit Enginsoy ve Burak Ege Bekdil, "Options Complicate Turkish Role in NATO Plan", Defense News, 29 Kasım 2010, s. 8; Gerrard Cowan, "Agreement on missile defence plan looks to include Russia", Jane's Defence Weekly, 1 Aralık 2010, s. 13. 
olduğu hakkında hiç kimsenin tereddüt duymadığı bir füze tespit radarının ABD tarafından Kürecik/Malatya'ya konuşlandırılmasına Ankara tarafından onay verilmesiyle, füze kalkanı iç siyasi tartışmaların ve kamuoyu gündeminin öncelikli konularından birisi konumuna yükselmiştir. Bu radara gerçekten gerek duyulup duyulmadığı, Türkiye'nin savunma ve dış politika dinamikleri üzerindeki yansımaları, iktidardaki hükümetin ABD ile ilişkileri, Kürecik'teki radarın İsrail'in füze savunmasına katkısının olup olmayacağı gibi muhtelif açılardan irdelenir ve hararetli şekilde tartışılır olmuştur. ${ }^{5}$

Soğuk Savaş'ın sona erdiği 1990'lı yıllardan bu yana Türkiye topraklarındaki ABD ve NATO askeri varlığının giderek azaldığı 20 yıllık sürecin tersine çevrilerek, bölgesel ve hatta küresel yansımaları olabilecek kritik önemdeki bir radar sisteminin ve ona bağl1 olarak NATO ve ABD'nin gelecek 15-20 yıllık döneme yönelik füze savunma mimarilerinde Türkiye'nin üstleneceği rolün hararetli tartışmalara yol açması doğaldır. Fakat bu bağlamda dikkat çeken husus, tartışmaların daha ziyade siyasi ve stratejik düzlemdeki görüş ve değerlendirmelerle sınırlı kaldığı, füze savunmasının teknik, teknolojik ve taktik boyutlardaki bazı temel kurallarını ve gerçeklerini tam manasıyla anlamadan gerçekleştirilen iddialı değerlendirme ve çıkışların çoğunlukla yetersiz, tutarsı, bazen de hatalı çıkarımlarla sonuçlanabildiğidir.

Takip eden sayfalarda, hem NATO hem de ABD ile ikili ittifak ilişkileri düzleminde Türkiye'nin gündemine taşınan füze tehdidi ve füze savunması konularındaki bazı teknolojik, teknik ve taktik gerçekler ile bunların olası stratejik ve siyasi yansımaları fazla teknik olmayan bir lisan ve içerikle incelenecektir. Bu inceleme sonucunda, teknolojik ve stratejik düzlemdeki gelişmelere paralel olarak Türkiye'nin füze kalkanı bağlamında karşı karşıya kalabileceği yeni konular, talepler, ikilemler ile yapılması gerekecek seçimlerin ortaya konması amaçlanmıştır.

\section{Balistik Füze Tehdidi}

İkinci Dünya Savaşı sırasında Nazi Almanyası tarafından geliştirilerek İngiltere ve Belçika'daki hedeflere karşı kullanılan balistik füzeler, askeri stratejinin birçok boyutu ve veçhesini geri dönüşü olmayan şekilde değiştirmiştir. ${ }^{6}$ Balistik füzeyi diğer saldırı silahlarından ayıran belki de en önemli özelliği, isminde barındırdığı "balistik" olgusunun bir yansıması olarak, fırlatılmasını takiben dik açıya yakın bir açıyla atmosferin üst tabakaları ve uzaya doğru süratle yükseldikten sonra dünyanın çekim gücüyle yavaşlayıp uçuşunun tepe noktasına ulaştığında, yer çekimini kullanarak bu kez daha büyük bir süratle hedefine doğru tepeden dalışa geçmesidir. Rakamsal bir örnek vermek gerekirse; 250 kilometre $(\mathrm{km})$

5 "Füze'yi Meclis'e sormak gerek", Cumburiyet, 20 Eylül 2011; Güldener Sonumut, "Füze kalkanı sistemiyle ilgili gerçekler", NTVMSNBC, 19 Eylül 2011, http://www.ntvmsnbc.com/ id/25251983/ (Erişim Tarihi: 29 Aralık 2011); Bahadır Selim Dilek, "Yeni Patriot'lar geliyor", Cumburiyet, 22 Ağustos, 2011; "Turkey Agrees to Host NATO Radar System”, Voice of America, 2 Eylül 2011.

6 Balistik füzelerin özellikleri, tarihçesi ve kullanımı hakkında daha kapsamlı bilgi için Bkz.: Sıtkı Egeli, Taktik Balistik Füzeler ve Türkiye, Ankara, Savunma Sanayii Müsteşarlığı, 1993, s. 2-31. 
menzile sahip, yani $250 \mathrm{~km}$ mesafedeki hedefleri vurabilecek kapasitedeki İkinci Dünya Savaşı'nın Alman $V$-2 füzeleri yerden $100 \mathrm{~km}$ (atmosfer-uzay sınırına) kadar yükselmekte ve yere doğru tekrar dalışa geçtiklerinde $2.500 \mathrm{~km} / \mathrm{saat}$, yani ses hızının 2 mislinden fazla bir sürate ulaşmaktadırlar. Balistik füzenin menzili arttıkça, ulaştığı irtifa ve buna bağlı olarak hedefine doğru dalışa geçtiğindeki sürati de artmaktadır. Örneğin, günümüzde İran'ın balistik füze envanterinin temelini oluşturan Şahap-3 füzelerinin $1.300 \mathrm{~km}$ menzilli türevi için tepe noktası takribi 300 km'ye, yani 100 km'de sona eren atmosferin bir hayli dışına, yere yaklaşma sürati ise $5.500 \mathrm{~km} / \mathrm{saat}$, yani ses hızının 5 misline yükselmektedir. $5.500 \mathrm{~km}$ ve daha üstündeki menzillere sahip kıtalararası balistik füzeler söz konusu olduğunda, tepe noktası artık uzayın derinlikleri sayılabilecek birkaç bin kilometreye, yere yaklaşma sürati ise ses hızının 10-15 misline ulaşmaktadır.

Yüksek sürat ve uçuşunun bir kısmını uzayda gerçekleştirerek hedefe doğru tepeden yaklaşma şeklinde özetlenebilecek bu ayırt edici özellikler, balistik füzelerin hedefinde olup korunma yolları arayan ülkeler açısından önemli bazı zorlukları beraberinde getirmektedir. Her şeyden önce 250-300 km civarında menzile sahip bir balistik füze için 3 dakika, $1.300 \mathrm{~km}$ menzile sahip bir füze içinse 10 dakikadan az olan uçuş süresi, hedef alınan ülkeye tanınan reaksiyon süresini başka hiçbir silah sisteminde görülmediği kadar kısaltmaktadır. Karşılaştırma olması açısından, aynı rakamlar 1.300 km menzile gitmeleri söz konusu olduğunda savaş uçakları için 1,5 saat civarındadır. Dolayısıyla, balistik füze saldırısının hedefindeki bir ülkenin firlatılan füzeyi tespit edip yere yaklaşık temas noktasını belirlemek, ardından bu noktada eğer varsa savunma önlemlerini devreye sokmak için sahip olduğu zaman dakikalar, hatta saniyeler mertebesindedir. Füze savunmasının özel gereksinimlerine göre yapılandırılıp elden geçirilmediği sürece, Dünya'daki hiçbir ülkenin klasik manadaki hava savunma önlemleri ve mimarisi, bu kadar kısa sürelerde reaksiyon verip arzu edilen sonuçları sağlayabilecek silah sistemlerine, komuta-kontrol unsurlarına, karar ve yetkilendirme süreçlerine sahip değildir.

Savunma önlemleri açısından ikinci zorluk, balistik füzelerin savaş uçakları ve diğer konvansiyonel hava tehditlerine kıyasla çok daha yüksek hedefe yaklaşma süratine sahip olmalarından, ayrıca alışılmışın dışında bir uçuş hattı izleyerek uçuşlarının önemli bir kısmını uzayda gerçekleştirdikten sonra yere neredeyse dik açıyla yaklaşmalarından kaynaklanmaktadır. Bu sıra dışı özellikler, bir ülkenin sahip olduğu ve atmosfer içinde uçan hedeflere karşı geliştirilmiş hava savunma silahlarını ve taktiklerini etkisiz ve çaresiz kılmaktadır. Hava savunma radarlarının pek çoğu balistik füzeleri tespit edecek tarama açı ve tekniklerine sahip değildir. Savaş uçakları da, balistik füzelere karşı etkili olabilecek silahlar taşımazlar. Normalde uçakları durdurmak üzere dizayn edilmiş uzun menzilli satıhtan-havaya füze sistemleri ise doğru zamanda ve doğru yerde, yani balistik füzenin hedefinin yeterince yakınında konumlanmış olsalar bile, "havadaki mermiyi başka bir mermiyle vurmak" şeklinde ifade edilebilecek füze savunmasının gerektirdiği manevra yeteneğine ve güdüm hassasiyetine sahip değillerdir. Sonuç olarak, füze savunmasının özel gereklerine göre tasarımlanmış veya tadil edilmiş algilayıcı ve silah sistemleri devreye sokulmadığ1 sürece, geleneksel hava savunma önlemleri balistik füze tehdidi karşısında çaresiz kalmaktadır. 
Balistik füzelere karşı savunma önlemlerini güçleştiren üçüncü bir husus ise nispeten kolay gizlenip taşınabilmeleri, ayrıca ateşlenmeleri için kapsamlı altyapı veya tesislere ihtiyaç göstermemeleridir. Dolayısıyla, balistik füzelere karşı "ön alma" (preemption) tabir edilen ve daha firlatılmadan önce yerde imha edilmelerine yönelik müdahaleler de kolaylıkla yapılamamaktadır. Balistik füzeler genelde bir ülkenin yollarında yüzlercesine rastlanabilecek sıradan kamyonlardan ayırt edilemeyen taşıyıcı araçlar üzerinde taşınmakta veya yer altındaki korunaklı silolarda muhafaza edilmektedir. Bunların geniş arazi dilimleri üzerinde bulunup imha edilmesi samanlıkta iğne aramaya benzetilebilir. Bu türden bir askeri harekât teoride mümkün olsa dahi, rakip ülkenin hava gücü ve hava savunma unsurlarının daha çatışmanın başında saf dışı bırakılması, büyük miktarda keşif ve muharip unsurun bu göreve tahsis edilmesi ihtiyacı ve girişimin başarıya ulaşması için uzun zamana ihtiyaç duyulacak olması gibi sebeplerle, gerçek hayatta uygulama bulması ve başarıya ulaşması zayıf bir ihtimaldir.

Tüm bu nitelikleri ve avantajlarından dolayı balistik füzeler, özellikle ileri ve modern bir hava gücünün gerektirdiği finansal, insan gücü veya teknolojik imkânlara sahip olmayan ülkeler açısından cazip bir seçenek olarak ön plana çıkmış ve komşularının üstün askeri gücüne karşı stratejik bir denge unsuru arayışı içerisindeki ülkelerce tercih edilir olmuşlardır.

Diğer taraftan, balistik füzelerin yukarıda değinilen avantajları kadar önemli dezavantajlarının bulunduğu da unutulmamalıdır. Her şeyden önce bunlar tek kullanımlık silahlar olup, hedefe nispeten küçük bir patlayıcı yükü taşımak için bu kadar pahalı bir taşı1ıı platformun feda edilmesi israf olarak nitelendirilebilir. Rakamsal olarak örneklemek gerekirse, ortalama bir balistik füzenin harp başlı̆̆ 500 ila $1.000 \mathrm{~kg}$ arasında değişirken, F-16 sınıfındaki bir savaş uçağı bunun 4-5 misli ağırlıktaki patlayıcı yükünü herhangi bir çatı̧̧mada defalarca, kullanım ömrü itibarıla da yüzlerce, hatta binlerce kez hedefine ulaştırabilmektedir. İlaveten, sadece önceden belirlenmiş hedeflere karşı kullanılabilen ve ateşlendikten sonra geri çağrılmaları veya farklı bir hedefe yönlendirilmeleri imkânı bulunmayan balistik füzelere kıyasla, savaş uçakları kendi hedeflerini bulup taarruz etme, ya da o an ortaya çıkan "firsat hedeflerine" saldırma esnekliğini tanımaktadır. Sonuçta, modern bir hava gücünün gerektirdiği mali, teknolojik ve insan gücü kaynaklarına sahip ülkelerin taktik silahlanma bağlamında tercihlerini balistik füzelerden yana kullanmadıkları görülmektedir.

Balistik füzelerin bir diğer ve stratejik dengeler açısından belki de en kritik zayıflı̆̆ı, özellikle bölgesel güçlerce konuşlandırılmakta olan görece eski teknolojiye sahip versiyonlarının isabet yüzdesinin çok düşük olması, dolayısıyla askeri veya stratejik açıdan kritik önem taşıyan nokta hedeflerine karşı etkinliklerinin yetersiz kalmasıdır. Başka bir ifadeyle, balistik füzeler konvansiyonel bir çatışmanın seyrini ve sonucu değiştiremeyecek denli zayıf silahlardır. Bu önemli dezavantajı aşmak için balistik füzelere sahip ülkelerin sahip olduğu seçenek, füzelerini nokta hedefi niteliği taşıyan askeri ve stratejik noktalardan ziyade, geniş alanlara yayılmı̧ büyük şehirlere, yani hedef ayrımı gözetmeksizin sivil nüfusa karşı bir nevi dehşet silahı olarak kullanılmasıdır. Bu kapsamda sahip olunan ve uluslararası dengeler açısından daha büyük kaygı uyandıran cazip bir seçenek ise, balistik 
füzelerin kitle imha silahları, yani biyolojik, kimyasal ya da tercihen nükleer başlıklarla donatılarak, düşük isabet yüzdesinden kaynaklanan zaaflarının kapatılmasıdır. İşte bu sebeple, herhangi bir bölgesel gücün balistik füzelere ilgi göstermeye başlaması, bu ülkenin er veya geç kitle imha silahlarına da ilgi duyacağı yönündeki kayg1 ve şüpheleri beraberinde getirmekte, balistik füzeler tekil ve bağımsız bir askeri yetenekten ziyade, kitle imha silahlarının yaygınlaşmasından duyulan kaygıların bir uzantısı olarak algılanmaktadır. Nitekim 1990'lı yıllarda Pakistan, Kuzey Kore, Irak ve Libya gibi örnekler, bir ülkenin balistik füzelere duyduğu ilginin nükleer silah elde etme çabalarının habercisi olduğu algılamasını teyit etmiştir. Günümüzde de İran'ın balistik füzelerinin sebep olduğu ciddi rahatsızlığın ve buna cevaben ABD, NATO ve İsrail tarafindan hayata geçirilmekte olan kapsamlı füze savunma önlemlerinin ardında, İran'ın askeri nitelik taşıdığından artık şüphe duyulmayan nükleer programının yarattığı kaygıların yattığı, İran’ın balistik füze stoklarının Tahran’n nükleer silah programının doğrudan bir uzantısı ve vurucu unsuru olarak algılandığı rahatllkla söylenebilir.

\section{Türkiye'ye Yönelik Tehdit}

Türkiye'nin komşuları arasında yer alan Sovyetler Birliği'nin 1950'li yıllardan itibaren giderek artan yetenek ve çeşitlilikte balistik füzeleri envanterine dâhil etmiş olması, ardından Soğuk Savaş’ın ilk evresinde ABD'nin Türkiye topraklarına nükleer başlık taşıyan Jupiter füzelerini konuşlandırması, Türkiye'nin içinde bulunduğu coğrafyanın balistik füzelere hiç de yabancı olmadığına işaret etmektedir. ${ }^{7}$ Diğer taraftan, Sovyetler Birliği'ne ait balistik füzeler Soğuk Savaş yıllarında Türkiye'nin tehdit algilamaları ve ulusal düzeydeki savunma planlamalarında kendine yer bulamamıştır. Bu durum açılamasını, Sovyetler'in balistik füze envanterinin bloklar arası nükleer dehşet dengesi perspektifinde algılanması bulmaktadır. Yıllar içerisinde Türkiye'nin Yunanistan haricindeki tüm komşuları (Suriye, Irak, İran, Bulgaristan) balistik füzelere sahip olmaya başladığında da Türkiye'nin füze tehdidine yönelik savunma politikaları, NATO çerçevesinde sahip olunan ya da en azından sahip olunacağına inanılan güvenlik garantileri üzerine şekillenmeye devam etmiş ve Batı İttifakı'nın sağladığ rin bölgesel güçlere ait füzeler karşısında da devreye gireceği varsayılmıştır. Fakat, daha önce de değinildiği üzere 1991 Körfez Savaşı ve 2003 Irak harekatı öncesinde bazı NATO müttefiklerinin İttifak'ın ortak savunma hükümlerini devreye sokarak Türkiye'nin yardımına koşmakta sergilediği isteksizlik, Türkiye'yi füze tehdidine yönelik olarak kendi ulusal politika ve savunma önlemlerini şekillendirmeye zorlamış, ama bu kez de füze savunmasının gerektirdiği astronomik mali kaynaklar ciddi bir engel olarak Türkiye'nin karşısına çıkmıştır. ${ }^{8}$

7 Thomas Blanton, "Annals of Blinksmanship", The Wilson Quarterly, Yaz 1997, http://www.gwu. edu/ nsarchiv/nsa/cuba_mis_cri/annals.htm (Erişim Tarihi: 6 Nisan 2012).

8 Şükrü Elekdağ, “Türkiye ve füze teknolojisi”, Milliyet, 15 Eylül 1997. 


\section{Suriye}

Suriye'nin 1960'lı yılların sonlarından itibaren Sovyetler'den önce Frog, daha sonra Scud tipi balistik füzeler alması, hatta bunları 1973 Arap-İsrail Savaşı'nda İsrail’e karşı kullanması Türkiye tarafindan Doğu-Batı blokları arasındaki dengeler çerçevesinde algılanmış, Sovyetler'in yakın müttefiki konumundaki Suriye'den kaynaklanacak herhangi bir tehdidin NATO'nun güvenlik garantileri kapsamında karşılık göreceği varsayımıyla hareket edilmiştir. ${ }^{9}$ Bu arada Suriye, 1980'li yıllardan günümüze balistik füze envanterini geliştirmeye ve çeşitlendirmeye devam etmiş, kimyasal başliklarla bir araya getirdiği en azından birkaç yüz balistik füzeden oluşan stoklarını İsrail'in tartışmasız hava üstünlüğü karşısında stratejik denge unsuru olarak kullanma yoluna gitmiştir. ${ }^{10}$ Suriye şu anda Türkiye'nin komşuları arasında İran'dan sonra kayda değer balistik füze stokuna sahip tek ülke olup, Ankara’ya kadar ulaşabilecek 600 km menzilli ve bazıları kimyasal harp başlı̆̆ taşıyan Suriye füzeleri, Şam’ın Ankara’ya karşı devreye sokabileceği belli bir caydırıcılı̆̆1 haiz belki de tek askeri yetenek konumundadır. Nitekim 1998'de PKK liderinin Türkiye'ye iade edilmesi bağlamında yaşanan gerginlik sırasında Suriye, Türkiye'yi balistik füze saldırısıyla tehdit etmiştir. ${ }^{11}$ Bu çerçevede, 2011'den itibaren zor günler geçirmeye başlayan Şam yönetiminin, aralarında Türkiye'nin de bulunduğu diş güçlerin olası müdahalesini caydıracak son koz olarak kimyasal başlıklı balistik füzelerini kullanma tehdidini gündemde tutması hiç de şaşırtıcı değildir. ${ }^{12}$

\section{Irak}

Türkiye'nin bir diğer komşusu Irak da uzun yıllar boyunca balistik füzeleri stratejik cayd1rıc1 gücünün önemli bir unsuru olarak kullanmış, hatta bu bağlamda caydırıcılığın ötesine geçerek balistik füzelerinden takribi 500'ini önce İran-Irak Savaşı sırasında İran'daki sivil hedeflere karşı, ardından 100'e yakın Scud füzesi türevini 1991 Körfez Savaşı'nda İsrail, Suudi Arabistan, Katar ve Bahreyn'deki hedeflere karşı kullanmıştır. ${ }^{13}$ 2003'de ABD tarafından işgale uğradıktan sonra Irak bu alandaki yeteneklerinden arındırılmış olup, işgal sonrası ABD ile tesis edilen ilişkilerin niteliği gereği, en azından kısa ve orta vadelerde tekrar balistik füze edinme yoluna gitmesi beklenmemektedir.

9 Suriye'nin balistik füze temin etme çabalarının tarihçesi ve stratejik gerekçeleri için Bkz.: Egeli, Balistik Füzeler, s. 75-79.

10 Alfred B.Prados, Syria: U.S. relations and Bilateral Issues, Congressional Research Service Report for Congress, Washington, D.C., 27 Temmuz 2006, s. 8-9, http://fpc.state.gov/documents/ organization/70195.pdf (Erişim Tarihi: 6 Nisan 2012).

11 Şamil Tayyar, "Yılmaz'dan Füze Uyarısı", Yeni Yüzyıl, 11 Eylül, 1998.

12 Mehmet Koca, “Suriye, füzelerini Türkiye’ye çevirdi”, Türkiye Gazetesi, 26 Kasım 2011.

13 Irak'ın balistik füze edinme çabaları ve kullanımına ilişkin daha kapsamlı bilgi ve değerlendirmeler için Bkz.; Egeli, Balistik Füzeler, s. 26-31. 
Tablo-1: Bölgedeki balistik füzeler. ${ }^{14}$

\begin{tabular}{|c|c|c|c|}
\hline & Menzil (km) & Menşei & Kullanan bölge ülkeleri \\
\hline Scud-B & 320 & SSCB, K.Kore & $\begin{array}{l}\text { Suriye, İran, Ermenistan, Gürcistan, } \\
\text { Rusya. }\end{array}$ \\
\hline Scud-C & 600 & K.Kore & Suriye, İran \\
\hline Şahap-3 & $1.300-1.900$ & İran (K.Kore) & İran \\
\hline Sejil-2 & $2.000+$ & İran & İran \\
\hline$D F-3(C S S-2)$ & 2.700 & Çin H.C. & Suudi Arabistan \\
\hline Jericho-2 & 1.500 & İsrail & İsrail \\
\hline Jericho-3 & 4.800 & İsrail & İsrail \\
\hline SS-26 İskender & 400 & Rusya & Rusya \\
\hline$S S-21$ Tocbka & 120 & SSCB & Suriye, Rusya, Ermenistan \\
\hline ATACMS & 145 & $\mathrm{ABD}$ & Türkiye, Yunanistan \\
\hline
\end{tabular}

\section{Iran}

İran'ın balistik füze programının kökeninde, İran-Irak Savaşı sırasında Irak'ın İran şehirlerine karşı balistik füze saldırıları düzenlemiş olması, İran’’n ise bu saldırılara kendi balistik füzeleriyle karşılık verme isteği yatmaktadır. ${ }^{15}$ İran, önceleri Libya daha sonra Kuzey Kore'den satın aldığı Scud füzelerini bir süre sonra kendi imkânlarıyla üretme yeteneğini kazanmakta gecikmemiş, savaşın sona ermesinden sonraki 20 yılda giderek daha uzun menzilli, daha güvenilir ve daha isabetli füzeler geliştirmiştir. Bugün geldiğimiz noktada İran, 600 km'ye kadar menzile sahip ve sayıları yüzler, belki binlerle ifade edilen pek çok farklı tipte balistik füzenin yanı sıra, kimi kaynaklarda 500 adedinin konuşlandırıldığı kaydı geçen Şahap-3 füzelerini de envanterine dâhil etmiştir. İlk versiyonları 1.100 ila $1.300 \mathrm{~km}, 2010$ 'da test edilen en yeni versiyonları ise takribi $1.600 \mathrm{~km}$, bir iddiaya göreyse $1.900 \mathrm{~km}$ menzile sahip Şahap-3 füzeleri Türkiye topraklarının tamamına ulaşabilmektedir. ${ }^{16} 2010$ sonundan itibaren sınırlı miktarlarda da olsa hizmete girmeye başladığına inanılan Sejil-2 füzesi ise, 2.000 km'nin üzerindeki menziliyle sadece Türkiye değil, Güney ve Doğu Avrupa ülkelerini de etki sahası içine almaktadır. ${ }^{17}$ Füzelerin menzilindeki bu etkileyici artışa paralel olarak, İran'ın balistik füzelerini daha isabetli ve daha güvenilir kılmak istikametinde de önemli adımlar attığı, ayrıca Şahap-3’te uçuşun belli bir anından

14 Rusya Federasyonu'nun nükleer caydırıcı gücünü teşkil eden kıtalararası balistik füzeler bu tablonun kapsamı dışında tutulmuştur.

15 İran'ın balistik füze edinme çabalarının kökeni ve kullanımına ilişkin daha kapsamlı bilgi ve değerlendirmeler için Bkz.; Egeli, Balistik Füzeler, s. 69-75.

16 Alon Ben-David, "Expanded Reach", Aviation Week \& Space Technology, 18-25 Temmuz 2011, s. 27-28; Duncan Lennox, "Iran could still extend an unclenched fist", Jane's Defence Weekly, 11 Şubat 2009, s. 40-42; Robin Hughes, "Long-Range Ambitions", Jane’s Defence Weekly, 13 Eylül 2006, s. 22-27.

17 Ben-David, "Expanded Reach”, s. 27-28; İbrahim Sünnetçi, “Lizbon Zirvesi NATO’nun Yeni Füze Savunma Stratejisi’nde Türkiye’nin Rolü!”, Savunma ve Havacılı, No.141, s. 146-149. 
sonra füze gövdesinden ayrılarak yoluna devam eden harp başlı̆̆ının, hatta bazı aldatma önlemlerinin dahi kullanılmaya başlandığı, dolayısıyla füzesavar sistemlerin İran füzeleri karşısındaki işinin giderek zorlaştığı anlaşılmaktadır. ${ }^{18}$

İran'ın önce komşu ülkeler ile İsrail, ardından Avrupa'daki hedeflere ulaşabilecek menzile sahip füzeleri envanterine dâhil etmesinin önemini misliyle artıran paralel süreç, son yıllarda İran'ın nükleer programının tüm engellemelere karşın istendiğinde nükleer silah yapımı için gerekli radyoaktif maddeleri sağlayabilecek olgunluğa ulaşması, dolayısıyla İran'ın balistik füze-nükleer başlık kombinasyonunun eşiğinde bulunmasıdır. ${ }^{19}$ Temelleri ülkenin Şahlık rejimiyle yönetildiği yıllarda uygulamaya aktarılan nükleer enerji çalışmalarına dayanan İran'ın nükleer programı, özellikle 1990'lı yıllardan bu yana istikrarlı bir şekilde gelişerek nükleer enerji tesisi inşası ve nükleer teknolojinin bilimsel veya tıbbi amaçlarla kullanımının ötesine geçmiş, uluslararası camianın şüphe ve kaygıyla izlediği uranyum zenginleştirme faaliyetlerine doğru genişlemiştir. ${ }^{20}$ Zenginleştirilmiş uranyumun aynı zamanda nükleer silahların da ana bileşeni niteliğini taşımasından duyulan kaygılar, Birleşmiş Milletler bünyesindeki Uluslararası Nükleer Enerji Ajansı'nın İran'da yaptığı denetimlerde nükleer harp başlı̆ğ tasarım ve test altyapısına dair somut bazı ipuçları tespit edilmesiyle daha ciddi ve acil bir hal almıştır. ${ }^{21}$ Nükleer silah emellerini gerçekleştirmiş bir İran, bölgesel bazı dengeleri alt üst etmenin ötesinde, Türkiye ile arasında son 500 yıldır varlığını koruduğu iddia edilen stratejik dengenin İran lehine bozulması gibi Türkiye'nin hiç hoşuna gitmeyecek bir olasıllı̆̆ da beraberinde getirmektedir. ${ }^{22} \mathrm{Bu}$ yönüyle İ̀an'ın sahip olduğu balistik füzeler, İran'ın nükleer silah emellerinin Türkiye'de sebebiyet verdiği tehdit algılamasının doğrudan bir uzantısı olarak ele alınmalıdır.

\section{Rusya}

Sovyetler Birliği'nden Rusya’ya geçen ve sayıları binlerle ifade edilen nükleer başlıklı k1talararası menzile sahip balistik füzelerin yanı sıra, Kızıl Ordu'ya ait önemli bir taktik balistik füze envanteri de Rusya Federasyonu tarafindan devralınarak Türk topraklarına ulaşabilecekleri Kafkaslar'daki Rus kuvvetlerinin emrine verilmiştir. ${ }^{23}$ Rus Ordusu'nca konvansiyonel kara harekâtında kullanılabilecek sıradan ve meşru silah sistemleri mua-

18 Ben-David, "Expanded Reach”, s. 27-28.

19 Mustafa Kibaroğlu, “İran bir nükleer güç mü olmak istiyor?”, Avrasya Dosyası, Güz 1999, s. 271-282.

20 "An Iranian nuclear bomb, or the bombing of Iran?", The Economist, 5 Aralık 2009, s. 27-29.

21 Lauren Gelfand, “UN reveals new evidence of Iran's nuclear designs”, Jane's Defence Weekly, 16 Kasım 2011, s. 6; Lauren Gelfand, "Iran plans to boost uranium enrichment", Jane's Defence Weekly, 15 Haziran 2011, s. 28.

22 Mustafa Kibaroğlu, "İran nükleer silah yaparsa en çok Türkiye zarar görür”, Voice of America, 6 Ocak 2012, http://www.voanews.com/turkish/news/ran-Nukleer-Silah-Yaparsa-En-CokTurkiye-Zarar-Gorur-136826253.html, (Erişim Tarihi: 6 Nisan 2012).

23 Dennis Gormley, "Prevent a Ballistic Missile Fire Sale”, Defense Nerws, 17 Şubat 1992, s. 3132; Thomas Ries, "Russia's Military Inheritance", International Defense Review, Mart 1992, s. 225; Duncan Lennox, "Missile Race Continues", Jane's Defence Weekly, 23 Ocak 1993, s.20; The Military Balance 1992-1993, Londra, International Institute for Strategic Studies, 1992. 
melesi gören bu balistik füzelerden bazıları, 2008'daki çatışmalarda Gürcistan'daki taktik ve stratejik hedeflere karşı ateşlenmiştir ve gelecekteki çatışmalarda da Rus konvansiyonel kuvvet yapısının bir parçası olarak tekrar kullanılmaları beklenmelidir. ${ }^{24}$ Belki daha da önemlisi Moskova'nın, NATO'nun füze kalkanı çerçevesinde kendisini tatmin eden bir noktaya varılamaması durumunda Güney Rusya'ya NATO'nun füze kalkanını hedef alan balistik füzeler konuşlandıracağı yönündeki tehditlerde bulunmasıdır. ${ }^{25}$ Dolayısıyla, gerek Karadeniz veya Kafkaslar'daki bir gerginliğin Türkiye ile Rusya’yı karşı karşıya getirmesi, gerekse Rusya'nın NATO füze savunma kalkanını hedef alması bağlamında, önümüzdeki dönemde Türkiye’ye yönelik Rusya kaynaklı bir balistik füze tehdidinden bahsedilebilir.

\section{Ermenistan ve Diğerleri}

Ermenistan'ın, 1990'lı yılların ortalarında Rusya Federasyonu'ndan 32 adet 320 km menzilli Scud füzesi temin ettiği yönündeki iddialar, 2011'de bu füzelerden bazılarının Erivan'daki bir resmigeçitte, hem de daha kısa menzilli ama daha modern $S S-21$ Tochka füzeleriyle birlikte boy göstermesiyle doğrulanmıştır. ${ }^{26}$ Ermenistan’ın sahip olduğu balistik füze sayısının Türkiye cüssesindeki bir ülkeye ciddi tehdit oluşturamayacak kadar küçük olduğu varsayılabilir. Bu çıkarımı değiştirebilecek uzak bir olasılık, Ermenistan'ın füzelerinin ülkedeki nükleer enerji santralinden temin edilebilecek radyoaktif atıkları firlatmakta kullanılması, yani bir nevi "kirli bomba" ya da "radyolojik silah" şekline dönüştürülmesidir.

Gürcistan'ın da aynen Ermenistan gibi 1990'larda Sovyetler'den devraldığı birkaç Scud füzesine sahip olması mümkündür. Bulgaristan ise Soğuk Savaş yıllarında Sovyetler Birliği'nden azımsanmayacak sayıda Frog, Scud ve SS-23 tipi balistik füze almış, fakat NATO üyeliği arifesinde bu füzeler imha edilmiştir. ${ }^{27}$ Kıbrıs Rum Kesimi balistik füze kategorisinde sistemlere sahip değildir. 1997 yılında Rusya'dan satın alınarak sonradan Kıbrıs yerine Girit'e konuşlandırılan S-300 sistemleri, isim benzerliği haricinde balistik füzelerle herhangi bir alakası bulunmayan ve sadece satıhtan-havaya kullanılabilen uçaksavar füzeleridir. Yunanistan'ın sahip olduğu $145 \mathrm{~km}$ menzilli ATACMS (Army Tactical Missile System) füzeleriyse, aynılarına Türkiye'nin sahip olduğu taktik saha kullanımına yönelik konvansiyonel silahlar olarak değerlendirilmelidir.

24 David A. Fulghum et al., "Georgian Military Folds Under Russian attack", Aviation Week E Space Technology, 15 Ağustos 2008, http:/www.aviationweek.com/aw/generic/story_generic. jsp?channel=awst\&id=news/aw081808p2.xml (Erişim Tarihi: 27 Kasım 2011).

25 Vladimir Ivanovski, "Füze kalkanında ssrar misilleme getirir", Cumburiyet, 4 Mart 2012. "Moskova'dan kalkan uyarısı", Cumburiyet, 24 Kasım 2011; "Russia warns of response to US missile shield”, Voice of America, 23 Kasım 2011, http://www.voanews.com/english/news/ europe/Medvedev-Accuses-USNATO-Ignoring-Russias-Worries-134400498.html (Erişim Tarihi: 27 Kasim 2011).

26 Grzegorz Holdanowicz, “Armenia shows new UAV”, Jane's Defence Weekly, 5 Ekim 2011, s. 22; Jeremy Binnie, "Radar affray: Israeli-Azeri contract threatens Iran", Jane's Defence Weekly, 28 Mart 2012, s. 21.

27 SS-23 Spider, http://www.globalsecurity.org/wmd/world/russia/ss-23.htm (Erişim Tarihi: 27 Kasim 2011). 
Türkiye'yle ortak sınırı bulunmadığı halde, son birkaç yıldır ortaya çıkan sürtüşme ve gerginlikler nedeniyle Türkiye'nin tehdit algılamalarına girdiği farz edilebilecek İsrail, Türkiye topraklarına ulaşabilecek menzilde balistik füze konuşlandıran bir diğer bölge ülkesidir. $1.500 \mathrm{~km}$ menzilli Jericho-2 füzelerinin takribi birkaç düzinesi ile ilki 2008'de test edilen yaklaşık $4.800 \mathrm{~km}$ menzilli Jericho-3 füzelerinin, İsrail'in sahip olduğu nükleer başıkları taşımak suretiyle ülkenin caydırıcı gücünün önemli unsurlarını teşkil ettiği sır değildir. ${ }^{28}$ Her ne kadar ulusal çıkarlar ve stratejik mülahazalar itibarıyla İsrail ile Türkiye arasında geniş çaplı bir askeri çatışma pek mümkün görünmese de, böyle bir çatı̧manın yaşanması durumunda İsrail'in sahip olduğu balistik füzeleri Türkiye'ye karşı kullanmasının zayıf bir ihtimal olduğu söylenebilir. Zira İsrail' in nükleer caydırıcı gücüyle özdeşleşmiş balistik füzelerini "sıradan" bir çatışmada devreye sokması, nükleer başlıkların sadece İsrail'in varlığına yönelik tehditlere karşı son çare silahı olarak elde bulundurulduğu yönündeki geleneksel İsrail söylemini geçersiz kılacaktır. Burada belirtilmesi gereken ilave bir nokta, İsrail'in 3.000km'ye kadar balistik füzeleri durdurabilecek yetenekte Patriot ve Arrow füze savunma sistemlerine sahip tek bölge ülkesi olduğudur. ${ }^{29}$

Özetlemek gerekirse, kendi başlarına ortaya koydukları tehdidin ötesinde nükleer silahların doğrudan bir uzantısı olarak görülmeleri sebebiyle balistik füzelerin, önümüzdeki 10 veya 20 yıllık zaman diliminde Türkiye'nin güvenliğine yönelik öncelikli dış askeri tehdit kategorilerinden birisini teşkil edeceği ve bu çerçevede balistik füze tehdidi etrafındaki tartışmalar ile girişimlerin de Türkiye'nin dış güvenlik ve savunma gündeminin öncelikli konusu ve meşguliyetini oluşturacağı öngörüsünde bulunulabilir. Tehdidin bir boyutunu, NATO'nun füze kalkanını engellemek veya geciktirmek gerekçesiyle Rusya'nın "kendine yakın NATO üyelerine yönelik balistik füze saldırılarında bulunmaktan çekinilmeyeceği" şeklinde Soğuk Savaş yıllarını çağrıştıran bir söylem içine girmiş olması oluşturmaktadır. ${ }^{30}$ İlaveten, "nükleer İran” faktörünün de önümüzdeki dönemde Türkiye'nin güvenlik ve savunma politikalarını şekillendirmekte daha fazla ağırlık taşıyacağı öngörülmelidir. Türkiye'deki siyasi otoritenin tepesinde bulunan bazı isimlerin bundan kısa süre öncesine kadar İran'ın nükleer programının askeri boyutunu ve Türkiye'nin güvenliği üzerindeki yansımalarını azımsayan diplomatik, ideolojik veya epistemolojik temelli bazı demeçleri bir yana ${ }^{31}, \mathrm{ABD}$ ve NATO'nun füze savunma kalkanı bağlamında Türkiye'nin son dönemde aldığı kararlar ve hükümetin İran'a yönelik eleştirel tutumundaki yükseliş Ankara’nın gerçek güvenlik ve savunma algılamalarının yerleştiği ekseni ortaya koymaktadır. ${ }^{32}$

28 "Israel launches leap in IRBM capabilities", Jane's Defence Weekly, 23 Ocak 2008, s. 5; Scott Johnson ve Emily Chorley, "Options to prevent a nuclear Iran: studies in preemption”, Jane's Defence Weekly, 28 Mart 2012, s. 28.

29 “Israel tests upgraded Arrow 2 system”, Jane's Defence Weekly, 2 Mart 2011, s. 19; Alon BenDavid, "Tit for Tat", Aviation Week E' Space Technology, 28 Şubat 2011, s. 24.

30 "Moskova'dan kalkan uyarısı", Cumburiyet, 24 Kasım 2011; Brooks Tigner, "Russia ramps up anti-BMD rhetoric", Jane's Defence Weekly, 30 Kasım 2011, s. 4.

31 "İran'ın nükleer silahı, dedikodudur", Dünya, 16 Mart 2010, http://www.dunya. com/\%E2\%80\%9Diranin-nukleer-silahi-dedikodudur\%E2\%80\%9D_81328_haber.html (Erişim Tarihi: 27 Kasım 2011); “Gül'den İsrail ve İran mesajları”, Radikal, 22 Eylül 2010.

32 "Erdoğan: Tahran ipe un seriyor”, Cumburiyet, 6 Nisan 2012; Nilgün Cerrahoğlu, "Tahran'a da Van Minüt!", Cumburiyet, 7 Nisan 2012. 


\section{Türkiye'nin Seçenekleri}

Türkiye'nin karşı karşıya bulunduğu balistik füze tehdidi düz mantık çerçevesinde ele alındığında, verilebilecek en doğrudan karşılık Türkiye'nin kendi balistik füzelerini geliştirip konuşlandırması gibi gözükebilir. Fakat tehdidin kaynağı konumundaki İran ve Suriye gibi komşularıyla karşılaştırıldığında, daha gelişmiş teknik ve teknolojik imkânlara sahip bulunan ve hem maliyet-etkinlik, hem de taktik/stratejik esneklik açılarından önemli avantajlara sahip hava gücünü tesis edebilmiş bir ülke olarak Türkiye'nin, ancak çok özel stratejik ve taktik şartlarda fayda sağlayan balistik füzelere yönelmesi gerçekçi ve isabetli bir seçenek değildir. Son dönemde balistik füzeler lehindeki demeçler ve başlatıldığ 1 iddia edilen çalışmalar, bu gerçeği değiştirmemektedir. ${ }^{33}$

$\mathrm{Bu}$ durumda Türkiye açısından bir kriz veya çatışma halinde balistik füze saldırılarının caydırılması, bu mümkün olmaz ise tehdit oluşturan füzelerin yerde veya havada saf dışı bırakılması, bir de hedefe ulaşmaları durumunda verebilecekleri zararı en aza indirecek önlemlerin alınmasıyla ilgili seçeneklerden bahsedilebilir. Türkiye’nin sahip olduğu gerek siyasi gerekse askeri güç temelindeki ağırlığın ve etkinliğin, bir kriz veya çatışma anında balistik füzelere sahip ülkeleri bunları kullanmaktan vazgeçirmek için zaten sonuna kadar devreye sokulacağı varsayılabilir. Tehdit oluşturan balistik füzelerin daha firlatılmadan tespit ve imha edilmesi, yani "karşı kuvvet" ya da "ön alma" tabir edilen harekât türü, daha önce balistik füze tehdidi kısmında da belirtildiği gibi balistik füzelerin yerdeyken tespitinin zor olması sebebiyle hem başarılı sonuçların garanti edilemeyeceği, hem de ihtiyaç göstereceği hava gücü unsurlarının fazlalığı itibarıyla Türkiye gibi bir bölgesel gücün imkânlarının ötesine geçen bir seçenektir. Hedefine ulaşan balistik füzelerin verdiği hasar veya can kaybının azaltılması ise esas itibarıyla pasif savunma veya sivil savunma önlemlerini ilgilendirmekte, Türkiye gibi geniş bir coğrafyaya yayılmış kalabalık nüfusa sahip ülkeler açısından, hele bir de nükleer başlıklarla donatılmış füzeler söz konusu olduğunda, gerçekçi ve uygulanabilir bir seçenek olmaktan çıkmaktadır. ${ }^{34}$

Dolayısıyla, füzelerin firlatıldıktan sonra tespit edilip daha hedeflerine ulaşmadan havadayken durdurulması seçeneği, yani "aktif” füze savunması, içerdiği teknolojik zorluklar ve getirdiği kabarık mali faturaya karşın diğer tüm seçenekler içerisinde en gerçek-

33 Türkiye açısından balistik füze - hava gücü edinimi karşılaştırması için bkz.: Egeli, Balistik Füzeler, s. 90-100. $500 \mathrm{~km}, 1.500 \mathrm{~km}$ ve $2.500 \mathrm{~km}$ menzilli füzelerin geliştirilmesine yönelik çalışmaların başlatıldığına dair Türk yetkililerce 2011 sonlarında yapılan açıklamalar, balistik füzelerden ziyade seyir (cruise) füzeleri bağlamında yapılmış olabilir. Bu kapsamda, balistik füzelere kıyasla daha ucuz ve daha isabetli oldukları için çok daha geniş taktik kullanım alanına sahip seyir füzeleri, Türkiye'nin mevcut teknoloji edinme ve tedarik programlarının doğal bir uzantısı olarak geliştirilip üretilebilecekleri için, yatırım ve tedarik maliyetleri açısından daha cazip bir seçenek teşkil etmektedir. "TÜBİTAK: Hedefimiz 2 bin 500 kilometre menzilli füze yapmak”, Hürriyet, 14 Ocak 2012; "Türk Füzesi SOM İçin Geri Sayım Başladı, Türkiye 2 bin 500 kilometre menzilli füze için gün sayıyor”, TRT, 13 Ocak 2012, http://www.trt.net.tr/ trtavaz/turk-fuzesi-som-icin-geri-sayim-basladi--haber-detay,tr,24107.aspx (Erişim Tarihi: 13 Nisan 2012).

34 Balistik füze tehdidi bağlamında karşı güç seçeneği ile pasif ve sivil savunma önlemlerinin daha detaylı bir analizi için Bkz.: Egeli, Balistik Füzeler, s. 101-108. 
çi ve uygulanabilir olanıdır. Buna karşılık Türkiye'nin son 20 yıl zarfında en azından üç kez balistik füze tehdidi altında kalmasına rağmen, Türk Silahlı Kuvvetleri bugüne kadar balistik füzelere karşı herhangi savunma yeteneği kazanmamıştır. Kitle imha silahları taşımadıkları sürece balistik füzelerin geniş çaplı bir çatışmanın akışı ve sonucu üzerinde fazlaca bir etkiye sahip olamayacakları, dolayısıyla Türkiye'nin üstün konvansiyonel saldırı yetenekleri karşısında balistik füzelerin ciddi bir tehdit ortaya koyamayacağı varsayımı bu durumu açılayan etmenlerin ilkidir. Gerçekleşecek bir füze saldırısında NATO ve $\mathrm{ABD}$ ile mevcut ittifak bağları ve savunma garantilerinin devreye gireceği beklentisi, füze savunmasına yönelik ulusal önlem ve kabiliyetlerin kazanılmasında yaşanan gecikmeyi açıklayabilecek ikinci bir etmendir. Balistik füzelere karşı etkin savunma sağlayacak ve geniş arazi dilimlerini koruyabilecek nitelikteki füze savunma sistemlerinin en azından 2000'li yıllara kadar ortaya çıkmamış olması, füze savunma teknolojisinin belli bir olgunluğa erişmesi sonrasındaysa bu kez de bu kategorideki sistemlerin gerektirdiği milyar dolarlar seviyesindeki mali kaynakların kolaylıkla tahsis edilememesi, bu konuda yaşanan gecikmenin üçüncü sebebi olarak gösterilebilir..$^{35}$

Sonuç itibariyle Türk Hava Kuvvetleri'nin yüksek irtifa hava savunmasını dayandırmaya devam ettiği Nike Hercules füzeleri 50 yaşını doldurmuş ve balistik füzeler bir yana, modern savaş uçaklarına karşı dahi etkinliklerini yitirmiş durumdadır. ${ }^{36} \mathrm{Hem}$ uçak, hem balistik füzelere karşı etkili olabilecek yeni nesil uzun menzilli hava savunma sistemlerinin satın alınmasına yönelik tedarik projeleri son 20 yıldır zaman zaman gündeme gelmiştir. ${ }^{37}$ Fakat, süratle hayata geçirileceği beklentisiyle projelendiren bu girişimler yürütülmekte olan diğer pek çok savunma teçhizat alımı arasından sıyrilarak bütçesel öncelik kazanamamı̧ ve bugüne kadar uygulamaya aktarılamamıştır. ${ }^{38} 2009$ 'dan bu yana teklif değerlendirme çalı̧̧aları devam eden LORAMIDS uzun menzilli hava/füze savunma projesi kapsamında mali kaynaklar tahsis edilse ve süratle karara varılarak sipariş verilebilse dahi, ihaleye konu sistemlerin performansı ve tedarik miktarları itibarılla sadece birkaç stratejik nokta veya şehire nispeten kısa menzilli balistik füzelere karşı koruma

35 Elekdağ, Füze Teknolojisi; Hava Kuvvetleri Komutanlığı, TSK'nde Hava ve Füze Savunması, s. 49.

36 İbrahim Sünnetçi, “Türk Hava Kuvvetleri Yarınlarını Tanımlıyor”, Savunma ve Havacılık, No: 147, s. $34,127$.

37 "Orduya 30 trilyonluk silah", Milliyet, 5 Şubat 1991; "200 Patriot için görüşme sürüyor", Milliyet, 9 Mart 1991; "Ordudan modernizasyon hamlesi", Milliyet, 22 Kasım 1994; "İran tehdidine İsrail füzesi”, Milliyet, 14 Mayıs 1997; “İran'a karşı füzesavar”, Milliyet, 9 Temmuz 2001; Mustafa Seven, “İstanbul ve Ankara’ya füze kalkanı”, Milliyet, 10 Ağustos 2008.

38 Türk Silahlı Kuvvetleri son 10 yıl içerisinde hava/füze savunma sistem tedariki ile aynı seviyede (birkaç milyar dolar) veya daha fazla mali kaynak gerektiren takip eden tedarik projelerini daha fazla bütçesel öncelik tanıyarak uygulamaya aktarmıştır: Havadan Erken İhbar ve Kontrol Uçağı, A400M nakliye uçağı, Keşif ve Taarruz Helikopteri, PO-III F-16 modernizasyonu, PO-IV üçüncü paket F-16 alımı, MİLGEM korvet, Havadan Bağımsız Tahrikli Denizaltı, Genel Maksat Helikopteri, F-35 Geleceğin Savaş Uçağı. Bkz.: Savunma Sanayii Müsteşarliğı Stratejik Plan 2012-2016, s. 32-33, http://www.ssm.gov.tr/anasayfa/kurumsal/Documents/ SP/Sp2012_2016/index.html (Erişim Tarihi, 5 Nisan 2012); Savunma Sanayii Müsteşarliğı 2010 Yıl Faaliyet Raporu, s. 46-59, http://www.ssm.gov.tr/anasayfa/kurumsal/Faaliyet\%20 Raporlar/2010/2010\%20Y\%C4\%B11\%C4\%B1\%20Faaliyet\%20Raporu.html (Erişim Tarihi: 10 Nisan 2012). 
sağlayan bir yetenek kazanılabileceği anlaşılmaktadır. ${ }^{39}$ İlaveten, pek çok NATO ülkesinin savaş gemilerine balistik füze tespit veya imha yeteneği kazandırma yönündeki adımlarının benzeri Türkiye tarafindan henüz atılmadığı için, istense dahi bu yetenekte hava savunma firkateynlerinin 2020 'li yılların ortalarından önce göreve başlamasının mümkün olamayacağı sonucu çıkmaktadır. Balistik füzelerin firlatıldıkları andan itibaren tespit, teşhis ve takibini yaparak füze savunma sistemlerinin hedeflerine angaje olabilmeleri açısından vazgeçilmez nitelikteki erken ihbar ile komuta-kontrol-haberleşme (commandcontrol-communication - $\mathrm{C}^{3}$ ) imkânları ele alındığında da, son birkaç yıldır NATO'nun $\mathrm{C}^{3}$ altyapısının Türkiye'deki uzantıları üzerinde NATO tarafından yapılmakta olan bazı iyileştirmeler haricinde, Türkiye'nin ulusal seviyedeki altyapısı ile karar süreçlerinin füze savunmasının özel gereklerine göre elden geçirildiği veya takviye edildiğine dair en azından kamuoyuna yansımıs herhangi bir işaret mevcut değildir.

Sonuç itibarılya, balistik füze tehdidi karşısında Türkiye'nin sahip bulunduğu tek gerçekçi seçenek aktif füze savunmasının tesis edilmesi olduğu halde, bugüne kadar bu alanda herhangi bir yetenek kazanılmadığı ve geleceğe yönelik projeler ile mali kaynaklar dikkate alındığında da bu nitelikteki ulusal önlemlerin en azından öngörülebilir bir gelecekte ve tüm ülkeyi kapsayacak bir çerçevede hayata geçirilemeyeceği anlaşılmaktadır. Dolayısıyla, hem günümüzde hem de geleceğe yönelik olarak mevcudiyeti yadsınamaz balistik füze tehdidi ve onunla bağlantılı nükleer tehdidin karşılanması ve etkisiz kılınması anlamında Türkiye'nin, stratejik değerlendirmelerin ötesinde biraz da füze savunmasının NATO üzerinden temininin sağladığı tasarruf boyutunu hesaba katarak, bu alanda ABD ve NATO ile ittifak bağlarına ve garantilerine güvenmeye devam ettiği söylenebilir. ${ }^{40} \mathrm{Bir}$ yandan İran etrafinda şekillenmekte olan balistik füze-nükleer silah kombinasyonunun yarattığı tehdit algısı, diğer yandansa Türkiye'nin füze savunmasına tahsis edebileceği nispeten sınırlı ulusal kaynaklar dikkate alındığında, Ankara’nın füze tehdidi karşısındaki tavrını ve politikalarını daha uzun süre NATO ve ABD'nin sağladığı savunma garantileri etrafında ve bu garantilerin bir uzantısını teşkil eden füze kalkanı çerçevesinde şekillendirmek zorunda kalacağı öngörüsü yapılabilir.

Hatta bir yönüyle, NATO ve ABD tarafindan tesis edilmekte olan füze savunma kalkanının, Soğuk Savaş yıllarının nükleer "genişletilmiş caydırıcılık" (extended deterrence) ve buna bağlı "mahrum bırakma yoluyla caydırıcillk" (deterrence by denial) kavramlarının bir uzantısı ve tamamlayıcısı niteliğini kazandığı, bir bakıma operasyonel manada nükleer caydırıcıllğı da içine alan yeni ve daha geniş bir çerçeve oluşturarak Türkiye'nin savunma konjonktürünün önemli bir unsuru haline geldiği söylenebilir. ${ }^{41}$

39 Sünnetçi, Lizbon Zirvesi, s.154; Ümit Enginsoy ve Burak Ege Bekdil, "Raytheon Touts Local Benefits In Turkish Missile Defense Bid”, Defense Nerws, 13 Haziran 2011.

40 “Savunma Bakanı Gönül: Füze Kalkanı tasarruf sağlayabilir”, Vatan, 15 Ekim 2010; “Türkiye’den iki koşul”, Cumburiyet, 15 Kasım 2010.

41 "Genişletilmiş caydırıcılık” yaklaşımında, ABD’nin müttefiklerine karşı bir saldırının gerekirse nükleer silahlar kullanılarak karşılıksız ve cezasız bırakılmayacağı mesajı verilerek saldırının caydırılması hedeflenmektedir. "Mahrum bırakma yoluyla caydırıcılık" yaklaşımında ise, ABD tarafindan devreye sokulacak etkili savunma önlemleri sayesinde, müttefiklere yapılacak bir saldırının askeri ve siyasi hedeflerine ulaşmasının ABD tarafından engelleneceği olgusu ağırlık 


\section{Füze Savunması ve NATO}

Bölgesel güçlerin elindeki nispeten ilkel balistik füzelerin ortaya koyduğu tehdidin ve bu tehdide karşı alınabilecek savunma önlemlerinin NATO'nun gündemine girmesi, 1991 Körfez Savaşı sırasında Saddam rejiminin füze saldırıları gerçekleştirmesi sayesinde olmuştur. NATO'nun füze savunmasına yönelik bakış açısı ve alabileceği önlemler 1991 Körfez Savaşı'nı takip eden dönemden itibaren yoğun tartışmalara ve çalışmalara konu olmuş, İttifak'ın güney ve doğu sınırlarında süratle yaygınlaşan balistik füzelere karşı korunma sağlayabilecek füze savunma yapılanması ve sistemlerine gerek duyulduğu üzerinde uzlaşma sağlanarak bu hususun NATO Stratejik Konsepti'ne dâhil edilmesi 1999'u bulmuştur. ${ }^{42}$ Ardından Haziran 2004'deki İstanbul Zirvesi'nde, "Aktif Kademeli Taktik Balistik Füze Savunması" (Active Layered Tactical Ballistic Missile Defense - ALTBMD) adıyla anılan bir füze savunma kalkanı kurulması için düğmeye basılmıştır. Bugün hala NATO'nun füze savunma mimarisi ve yetenekleri için ana çerçeveyi oluşturmaya devam eden ALTBMD ile İttifak askeri kuvvetlerine 3.000 km'ye kadar menzili olan balistik füzelere karşı korunma sağlanması hedeflemiş, bu amaçla NATO'nun $C^{3}$ altyapısının füze savunmasının gereklerine göre yeniden yapılandırılması kararlaştırılmıştır. Buna karşılık, füze savunmasının asıl vurucu unsuru olan önleyici füzelerin üye ülkelerin sahip olduğu ve ihtiyaç halinde İttifak’a tahsis etmelerinin beklendiği sistemlerden oluşması kararlaştırılmıs, yani NATO'nun kendine ait önleyici füzelere sahip olmayacağı bir çerçeve benimsenmiştir. Benzer şekilde, bazı üye ülkelerin tehdidin niteliği ve acilliği konusundaki çekinceleri, ayrıca ihtiyaç duyulan fakat ortada olmayan çok büyük çaplı mali kaynakların bir yansıması olarak, sivil hedefler ile NATO ülkelerindeki nüfusun korunması ilk safhada ALTBMD'nin kapsamı dışında bırakılmıştır. ${ }^{43}$ Ama bu durum uzun sürmemiş ve Nisan 2008'deki Bükreş zirvesinde sadece askeri birlikler ile yüksek değer taşıyan hedeflerin değil, tüm NATO toprakları ile sivil nüfusun da füze şemsiyesi kapsamına alınması karara bağlanmıştır. Bu önemli gelişmeye vesile teşkil eden ise, ABD'nin kendi topraklarını korumak için ABD anakarasında hizmete sokmaya başladığı "Karada Konuşlu Yarı Yol Savunma Sistemi”" (Ground Based Mid-Course Defense System - GMD) füze savunma sisteminin Avrupa'ya yerleştirilecek ileri unsurlarının, ABD’nin baskısı ve zorlu pazarlıklardan sonra NATO'nun füze savunma mimarisine dâhil edilmesi olmuştur. ${ }^{44}$

Burada değinilmesi gereken önemli bir husus, gerek Ortadoğu kaynaklı füze tehdidinin öncelikli bir konu olarak ele alınması, gerekse füze savunması alanında artık sa-

kazanmaktadır. ABD stratejisinin bu konuda son yıllarda geçirmekte olduğu dönüşüm için bkz.: Michael Bruno, Bettina H. Chavanne ve Bill Sweetman, "Closing Pandora's Box", Aviation Week and Space Technology", 12 Nisan 2010, s. 24-25.

42 NATO'nun füze savunma alanında geçtiği aşamaların incelenmesinde faydalanılan başlıca kaynaklar: Ian Davis, "NATO and Missile Defence", Military Technology, 2/2005, s. 55; John C. Rood, "BMD after Bucharest NATO Summit", Military Technology, 8/2008, s. 18; "Missile Defence: The Alliance Perspective", Report to NATO Parliamentary Assembly, Military Technology, 8/2008, s. 19-25.

43 Davis, "NATO and Missile Defence”, s. 55; Rood, "BMD after Bucharest”, s. 18.

44 Amy Butler ve Robert Wall, "Defense Complex”, Aviation Week \& Space Technology, 17 Kasım 2008, s. 26-27. 
hip olmaya başladığı kayda değer yetenekler itibarıla ABD'nin 1990'l yıllardan itibaren NATO içerisinde bu alanda yürütülen çalışmalarda lokomotif rolünü üstlendiği, Avrupalı müttefiklerini füze tehdidinin ciddiyetine ve bir an önce somut tedbirler alınmasının gerekliliğine ikna etmeye çalı̧an ülke görüntüsü çizdiğidir. Başkan Reagan'nn 1983'teki ünlü "Yıldız Savaşları" konuşmasından itibaren ABD anakarasını balistik füze tehdidinden koruyacak teknoloji ve sistemlerin geliştirilmesi için yoğun çaba ve kaynak harcayan ABD, Soğuk Savaş sonrası dönemde Sovyetler Birliği kaynaklı füze tehdidinin önceliğini yitirmesiyle füze savunması alanındaki harcamaların gerekçilendirmesini Irak, Kuzey Kore ve İran gibi bölgesel güçlere yöneltmiştir. ${ }^{45}$ Bu kapsamda, ABD’nin 2000'li yıllarda Avrupalı müttefiklerinin önüne getirdiği teklif, $\mathrm{ABD}$ anakarasını korumaya yönelik $\mathrm{ABD}$ mülkiyetindeki GMD sistemine ait bazı radarlar ile önleyici füzelerin "Üçüncü Mevzi” adı verilen bir yaklaşım çerçevesinde süratle Avrupa'ya yerleştirilmesidir. ${ }^{46}$ Avrupa'nın kendisinden ziyade ABD anakarasının savunmasına hizmet edeceği algılamalarına yol açan bu teklif, Polonya ve Çek Cumhuriyeti gibi Rusya'yı hala birincil tehdit olarak gören bazı Doğu Avrupa ülkelerinin verdiği destek ve 2008 Bükreş Zirvesi’nde alınan lehte karara rağmen ilerleme kaydedememiştir.

Bu kapsamda belki daha da önemlisi, Ortadoğu kaynaklı ya da daha doğrudan bir ifadeyle İran kaynaklı balistik füzeleri durdurmak üzere Avrupaya yerleştirilmesinin gerektiği savlanan ABD füze kalkanına ait "Üçüncü Mevzi” unsurlarının, aynı zamanda Rus kıtalararası füzelerini de düşürülebilecek olmasından endişe duyan Rusya Federasyonu'nun şiddetli tepkisi ve direnciyle karşılaşmı̧̧ olmasıdır. Rusya'nın itirazları İttifak'ın Avrupalı üyelerinden bazılarının tereddütleriyle birleştiğinden, NATO'nun füze kalkanı girişimi bu yıllarda belli bir duraklama evresine girmiştir. ${ }^{47}$

En nihayet, 2009'da ABD'de Obama Yönetimi'nin görevi devralması ve ABD'nin anakara füze şemsiyesinin ileri unsurlarının Avrupa'ya yerleştirilmesi ısrarını bir kenara bırakarak, Eylül 2009'da “Avrupa Aşamalı Uyum Yaklaşımı” (European Phased Adaptive Approach - EPAA) adı verilen yeni bir füze savunma yaklaşımını masaya sürmesiyle NATO'nun füze kalkanına yönelik çalı̧̧maları tekrar ivme kazanabilmiştir. Bu kapsamda Obama Yönetimi, İran gibi bölgesel güçlerin balistik füze yeteneklerinde yaşanacak gelişmelere paralel olarak yıllar içinde ve fazlar halinde uygulamaya aktarılacak daha esnek

45 1983-2011 döneminde ABD’nin füze savunma çalışmalarına harcadığı meblağ 150 milyar dolar olarak tahmin edilmektedir. Bkz.: Eliot Blair Smith ve Gopal Ratnam, “\$35B missile defense misses bullet with bullet”, Bloomberg, 3 Ağustos 2011, http://www.bloomberg.com/news/201108-03/missile-defense-costing-35-billion-misses-bullets-with-bullets.html (Erişim Tarihi: 10 Nisan 2012).

46 Burada “Üçüncü Mevzi”den kasıt, Kaliforniya ile ABD’nin Doğu kıyısındaki ilk iki GMD mevzisinden sonra üçüncü mevzinin Avrupa'da tesis edilmesidir. Bkz.: Michael Sirak, "The End Game”, Jane's Defence Weekly, 15 Eylül 2004, s. 24-29.

47 Vladimir Petrov, "Russia plans to counter missile defence shield", Jane's Defence Weekly, 12 Kasım 2008, s. 6; Dmitry Rogozin, "Missile defence as a common cause for all", Jane's Defence Weekly, 21 Ekim 2009, s. 20; Duncan Lennox, "US and Europe must aim to please Russia", Jane's Defence Weekly, 25 Mart 2009, s. 20-21. 
bir füze kalkanı yaklaşımı önermiştir. ${ }^{48}$ Biraz daha açmak gerekirse, EPAA kapsamında ABD, ALTBMD çerçevesinde NATO'nun kazanmaya başladığı $\mathrm{C}^{3}$ altyapısına paralel olarak 2011'den itibaren Avrupa denizlerine önleyici füzeler taşıyan ABD savaş gemileri, 2015'ten itibarense karada konuşlu önleyici füzeler konuşlandırmayı ve bunların yeteneklerini yıllar içerisinde hem tehdit seviyesinde, hem de teknolojideki gelişmeler paralelinde artırmayı önermiştir. ${ }^{49}$ EPAA planının en azından 2020'ye kadarki safhalarında konuşlandırılması hedeflenen önleyici füzeler Rusya'nın kıtalararası balistik füzelerine ciddi bir tehdit oluşturmamaktadır. Ayrıca, ABD'nin kendi topraklarını korumaya yönelik kıtalararası füze kalkanı ile Avrupa'da oluşturulacak bu yeni füze savunma kalkanı arasındaki doğrudan ilişki de EPAA sayesinde zayıflamıştır. Bu sayede, EPAA daha önceki ABD önerisinden daha geniş kabul görmüş ve Kasım 2010'daki Lizbon Zirvesi'nde askeri kuvvetlerin yanı sıra bundan böyle sivil nüfus ve İttifak topraklarının tamamının da füze saldırılarından korunması için adımlar atılmasını öngören yeni İttifak füze savunma stratejisinin kabulüne zemin hazırlamıştır. Lizbon Zirvesi’nde oluşan uzlaşma doğrultusunda NATO, ALTBMD çerçevesinde tesis edilmesine zaten başlanmış olan $\mathrm{C}^{3}$ altyapısının yeteneklerini tüm ittifak topraklarının ve nüfusun korunmasına izin verecek şekilde geliştirilmesini kararlaştırmış, önleyici füzelerin ise eskiden olduğu gibi İttifak’a üye ülkelerce tahsis edilecek sistemlerden oluşacağı, bu kapsamda ABD'nin EPAA kapsamında Avrupa'ya konuşlandıracağı radar ve önleyici füzelerin NATO füze kalkanının merkezinde yer alması kabul görmüştür. ${ }^{50}$

NATO zirvelerinde alınan bu iddialı karar ve açıklamaları bir kenara bırakarak ALTBMD çerçevesinde edinilmekte olan yetenekleri teknik yönüyle ele alırsak, NATO'nun füze savunma alanındaki çalışma ve hazırlıklarının gerçek niteliği ve içeriği hakkında farklı bir tablo ortaya çıkmaktadır. Bu manada ALTBMD esas itibarıyla bir yazılım paketidir ve ana işlevi çeşitli NATO ülkelerine ait birbirinden farklı çalışma özelliklerine sahip algılayıcıların verilerini bir araya getirecek ara yüzü sağlamasıdır. Bu suretle oluşturulan balistik füze tehdidine ait taktik resim, NATO'nun yetenekleri artırılmakta olan mevcut $\mathrm{C}^{3}$ ağı üzerinden İttifak genelindeki kullanıcılara, yani sevk ve idare işlevini yürütecek karargâhlar ile yaklaşmakta olan füzelerin yere düşme noktaları yakınındaki savunma unsurlarına ulaştırılacaktır. ${ }^{51} \mathrm{Bu}$ yönüyle ALTBMD, füze savunmasına yönelik olarak sadece taktik resim sunmaktan ibaret pasif bir işlev yerine getirmekte, buna karşılık tehdit oluşturan füzelerin hangi savunma unsurlarınca önleneceğine yönelik görevlendirme ve merkezi kontrolü yerine getirememekte, ayrıca önleyici sistemlerin hedeflerine angaje olmasını kolaylaştıracak hassasiyetteki hedef bilgilerini de sunamamaktadır. $\mathrm{Bu}$

48 The Phased Adaptive Approach for Missile Defense of Europe, Fact Sheet by Missile Defense Agency, 17 Eylül 2009, http://www.mda.mil/system/paa.html (Erişim Tarihi: 14 Nisan 2012).

49 Patrick O'Reilly, Ballistic Missile Defense Overview - European Phased Adaptive Approach, Missile Defense Agency, Washington, D.C., 18 Ekim 2011, s. 3-8.

50 Robert Wall, “Alliance Agenda”, Aviation Week E Space Technology, 29 Kasım 2010, s. 26.

51 Dağıtımı ve paylaşımı yapılan taktik resim esas itibariyle İttifak bünyesindeki karargâhlar ile kullanıcılara ulaştırıldığı halde, bir kez ülkelerin ulusal komuta-kontrol-muhabere sistemine dahil olduktan sonra bu verilerin ulusal seviyedeki karargah, kullanıcı ve birliklerce görülmesi ve kullanılmasının önünde herhangi bir engel yoktur. 
alanda asıl kapsamlı yeteneklere sahip olan, örneğin uzayda konuşlu balistik füze erken ihbar uydularını NATO kullanımına tahsis edebilen tek İttifak üyesi ABD olup, son 30 yıldır füze savunması alanına yaptığı yatırım ve edindiği kendi kendine yeterli altyapı itibarıyla, NATO'nun ALTBMD yapılanmasının komuta-kontrol-haberleşmesini sırtında taşıyan ülke ABD'dir. ${ }^{52}$

Benzer durum önlemeyi yapacak füze savunma sistemleri için de geçerlidir. ALTBMD kapsamında Avrupa ülkelerinin İttifak'ın füze savunmasına tahsis edebildiği bir avuç önleyici füze, görece kısıtlı performansa sahip ve sadece "alt katman" (lower tier) savunması tabir edilen ve balistik füzelerin artık hedeflerine ulaşmak üzereyken vurulmasına imkân taniyan sistemlerdir. NATO'ya üye 28 ülke arasından ABD haricinde sadece Hollanda ve Almanya görece uzun menzili $(1.000 \mathrm{~km})$ balistik füzeleri düşürebilecek Patriot PAC-3 önleyici füzelerine, o da kısıtlı miktarlarda sahiptir. Fransa ve İtalya'nın NATO'ya tahsis ettiği füzesavar sistemler, $600 \mathrm{~km}$ 'den daha uzun menzile sahip balistik füzelere karşı etkisizdir. ${ }^{53}$

2010 Lizbon Zirvesi'nde alınan kararlar açısından belki daha da çarpıcı olanı, sadece alt katman füze savunması yapabilen bu sistemlerin kendi bulundukları noktanın etrafındaki dar bir alanı koruyabilmeleri, dolayısıyla sivil nüfusun ve tüm İttifak topraklarının korunmasını öngören yeni NATO stratejisinin, ABD'nin imkânları devreye girmediği sürece ne kısa ne de orta vadede uygulamaya aktarılma şansının zaten bulunmamasıdır. Geniş coğrafi alanların savunulabilmesi için hedefine doğru yol alan balistik füzeleri atmosferin üst tabakalarında veya uzayda vurabilen çok daha yüksek teknolojili ve maliyetli üst katman veya "yarı yol" (mid-course) safhası önleyici füzelere ihtiyaç duyulmaktadır. Şu an için Avrupa ülkelerinden hiçbirinin bu kategoride savunma sistemleri geliştirilmesi veya alınmasına yönelik elle tutulur bir program1 mevcut değildir. ${ }^{54}$

Sonuç itibarıla, NATO'nun füze savunmasına yönelik ALTBMD girişimi ABD'nin sahip olduğu ve Avrupa'nın savunmasına tahsis ettiğgi imkânlar ve yetenekler üzerine şekillenmek durumundadır. ABD’nin dünyanın herhangi bir köşesinde füze savunması yapabilmek için ALTBMD'ye, NATO'ya veya Avrupa'ya ihtiyacı yoktur. Fakat bunun tersi NATO'nun Avrupalı üyeleri için geçerli değildir. Bu durumda, özellikle 1.000 $\mathrm{km}$ üzerindeki menzillere sahip balistik füzelerin durdurulması söz konusu olduğunda, NATO füze kalkanına yönelik tüm analiz ve tartışmalar, ABD'nin EPAA çerçevesinde Avrupaya sağlamayı taahhüt ettiği füze savunma önlemleri ve yeteneklerine indirgenmektedir.

52 "Interview with ALTBMD Chief Alessandro Pera", Defense News, 5 Nisan 2010, s. 8; Brooks Tigner, "NATO to step up ALTBMD tests", Jane's Defence Weekly, 14 Eylül 2011, s. 19; Brooks Tigner, "NATO progresses missile defence C2 plans", Jane's Defence Weekly, 14 Temmuz 2010, s. 25 .

53 NATO Source Alliance News Blog, http://www.acus.org/natosource/video-first-live-fire-testnatos-missile-defense-system (Erişim Tarihi: 10 Nisan 2012); Charles Hollosi, "European fleets respond to ballistic missile threats", Jane's Navy International, Eylül 2011, s. 28-29.

54 Amy Butler, "Missing Link", Aviation Week E' Space Technology, 22 Ağustos 2011, s. 23. 
Bu yönüyle, Soğuk Savaş yıllarında ABD’nin Avrupa'daki müttefiklerine sağladığ1 taktik nükleer silahlara dayalı "genişletilmiş caydırıcılık" garantilerinin, Soğuk Savaş sonrasında dönüşümden geçerek "mahrum bırakma yoluyla caydırıcılık" olgusuna evrildiği söylenebilir. Genişletilmiş caydırıcılıkta, ABD'nin müttefiklerine karşı bir saldırının gerekirse nükleer silahlar kullanılarak karşılıksız ve cezasız bırakılmayacağı mesajı verilerek saldırının caydırılması hedeflenmekteydi. Mahrum bırakma yoluyla caydırıcılık yaklaşımında ise, ABD tarafindan devreye sokulacak etkili savunma önlemleri sayesinde, müttefiklerine yapılacak bir saldırının amaçlarına ulaşmasının ABD tarafından engelleneceği olgusu ağırlık kazanmaktadır. Bu yönüyle Avrupa’nın balistik füzelere karşı savunulması için ABD tarafindan tahsis edilmekte olan kaynaklar, Soğuk Savaş sonrası dönemde önemi artan "mahrum bırakma yoluyla caydırıcıllk" doktrininin önemli bir unsurunu teşkil etmektedir. ${ }^{55}$

\section{ABD'nin Füze Savunma Yetenekleri ve EPAA}

ABD, 1980’li yıllardaki “Stratejik Savunma Girişimi” (Strategic Defense Initiative - SDI), ya da kamuoyunun daha iyi tanıdığı ismiyle "Yıldız Savaşları" programından başlayarak füze savunmasına büyük kaynaklar ayıran ve $\mathrm{ABD}$ anakarasına yönelik balistik füze tehdidinin bertaraf edilmesini bir ulusal savunma önceliği olarak ele alan bir ülkedir. ABD, 1991'deki Körfez Savaşı'ndan çıkarılan dersler doğrultusunda, Kuzey Kore veya İran benzeri bölgesel güçlerce nispeten kısıtlı sayıda ama kitle imha silahı taşıyan balistik füzelerle $\mathrm{ABD}$ anakarası veya $\mathrm{ABD}$ 'nin denizaşırı askeri unsurları ile yakın müttefiklerine karşı düzenlenebilecek saldırıların etkisiz kılınması yönünde büyük çaba ve kaynak harcamış ve harcamaya da devam etmektedir. ABD'nin bu alanda ulaştığ teknolojik seviye ve edinmeye başladığı kabiliyetler, dünyanın geriye kalanının 10 belki 20 yıl ilerisindedir. Vaşington'un bu alandaki projelere her yıl tahsis ettiği 10 milyar mertebesindeki mali kaynak ve ABD’nin teknolojik imkânları göz önüne alındığında, önümüzdeki 20 yıllık zaman diliminde bu farkın kapanması mümkün görünmemektedir. ${ }^{56}$

Kendi başına bir kitap konusu olabilecek çeşitlilik ve karmaşıklıktaki ABD’nin füze savunmasına yönelik kabiliyet, program ve planlarını detaylandırmak yerine, bu çalışmada ABD'nin Avrupa ve NATO'nun füze savunmasına tahsis etmeyi önerdiği sistemlerin EPAA tarafindan sınırları çizilen çerçevede incelenmesiyle yetinilecektir.

55 Baker Spring, "Europe, Missile Defense, and the Future of Extended Deterrence", WebMemo, No.2080, Washington, D.C., The Heritage Foundation, 25 Eylül 2008, s. 1-2; Manpreet Sethi, "New Face of Security: Missile Defense Rewrites Nuclear Strategies", Defense Nerws, 16 Ocak 2006, s. 21; Michael Rühe, "NATO and Extended Deterrence in a Multinuclear World", Military Technology, 4/2009, s. XXXIII-XXXIX.

56 Eliot Blair Smith ve Gopal Ratnam, “\$35B missile defense misses bullet with bullet”, Bloomberg, 3 Ağustos 2011, http://www.bloomberg.com/news/2011-08-03/missile-defense-costing-35billion-misses-bullets-with-bullets.html (Erişim Tarihi: 10 Nisan 2012); Philip Coyle, "Ask McCain and Obama about Missile Defense”, Center for Defense Information, 16 Eylül 2008, http://www.cdi.org/friendlyversion/printversion.cfm?documentID=4371 (Erişim Tarihi: 14 Nisan 2012). 
1990'larda Avrupa'ya yönelik olarak Ortadoğu kaynaklı bir balistik füze tehdit algılamasının ortaya çıkmasıyla birlikte, savunma önlemleri anlamında ABD'nin bu tehdide verdiği karşılığın temelinde, tehdit altında olduğu düşünülen ülkelere veya bölgelere konuşlandırılan Patriot hava savunma sistemleri yer almıştır. Hatırlanacağı üzere, 1991 ve 2003 Irak savaşları ile daha yakın geçmişte Suriye'de yaşananlar karşısında ABD, Almanya ve Hollanda tarafindan Türkiye'nin güneydoğusundaki birkaç hava üssü ile kentin korunması için konuşlandırılan savunma sistemleri Patriot'lar olmuştur. ${ }^{57}$

Patriot, 1980'lerde öncelikle savaş uçaklarını durdurmaya yönelik olarak tasarımlanmış, ama yıllar içerisinde balistik füzelere karşı da etkili olacak şekilde tadilattan geçirilmiştir. Bugün gelinen noktada Patriot sisteminin en yeni $P A C-3$ türevi, 1.000 km'ye kadar menzile sahip balistik füzeleri vurabilecek yetenektedir. Yalnız Patriot, "alt katman" tabir edilen ve balistik füzenin hedefine doğru yolculuğunun son aşamasını oluşturan atmosfer içerisindeki uçuş safhasında önleme yapabilecek kapasitede bir sistemdir. Daha uzun menzilli balistik füzelerin uçuşlarının bu son safhasında ulaştığı süratler çok arttığı için, Patriot sistemi 1.000 km'den daha uzun menzilli füzeler karşısında etkisiz kalmakta, bu kategorideki füzelerin önlenebilmesi için atmosfer-uzay geçiş noktası veya uzayda önleme yapabilecek "üst katman" tabir edilen füze savunma sistemlerinin devreye sokulması gerekmektedir. Ayrıca, önleme yapılan irtifanın ve buna bağlı olarak izdüşümündeki alanın görece az olması sebebiyle, Patriot sistemleri ile sadece kritik önemdeki birkaç tesis veya şehir korunabilmekte, daha geniş alanların veya örneğin bir ülkenin tamamının koruma altına alınabilmesi için düzinelerce hatta yüzlerce Patriot bataryasına ihtiyaç duyulmaktadır, ki bu mali açıdan uygulanabilir bir seçenek değildir. Önleme irtifasının az olması sebebiyle yaklaşmakta olan füzenin 1skalanması halinde ikinci bir deneme yapmaya vakit kalmaması, alt katman füze savunma önlemleri ve dolayısıla Patriot 1 in bir diğer zayıf yönüdür. Tehdit füzenin hedefinin hemen üzerinde vurulması sebebiyle, eğer nükleer başlık taşıyorsa bu başlığın infilak etmesi ihtimalinin hala bulunması, ya da nükleer başlık devreye girmese dahi füzenin imhası sonucunda açığa çıkacak radyoaktif maddelerin serpinti halinde hedefe ulaşması da Patriot sınıfindaki alt katman füze savunma sistemlerinin zayıf yönleri arasında yer almaktadir. ${ }^{58}$

57 Ufuk Güldemir, "Patriot'lar ne kadar güvenli?”, Cumburiyet, 26 Ocak 1991; Nicholas Fiorenza, "In Reprise of 1991 Role, Dutch Patriots Deploy to Turkey", Defense News, 17 Mart 2003, s. 23.

58 Robert Wall, "War", Aviation Week E Space Technology, 24 Mart 2003, s. 24-25; Amy Butler, "Terminal Range", Aviation Week \& Space Technology, 15 Eylül 2008, s. 46-47; "Netherlands decides to procure Lockheed PAC-3 missiles", Jane's International Defence Review, Nisan 2004, s. 12. 
Tablo-2: Füze Savunma Sistemleri. ${ }^{59}$

\begin{tabular}{|c|c|c|c|}
\hline & $\begin{array}{l}\text { Önleme } \\
\text { yapabildiği balistik } \\
\text { füzenin menzili } \\
(\mathrm{km})\end{array}$ & Önleme irtifası & $\begin{array}{l}\text { Hizmete } \\
\text { girdiği / } \\
\text { gireceği yıl }\end{array}$ \\
\hline Patriot PAC-2 & 600 & Alt katman $(\sim 12 \mathrm{~km})$ & 1990 \\
\hline Patriot PAC-3 & 1.000 & Alt katman $(20-40 \mathrm{~km})$ & 2002 \\
\hline THAAD & $1.000-3.000$ & Atmosfer içi ve dış1 $(100-150$ km) & 2010 \\
\hline$S M 3-I A$ & 3.000 & Atmosfer diş1 & 2006 \\
\hline$S M 3-I B$ & $3.000-5.500$ & Atmosfer diş1 & 2015 \\
\hline$S M 3-I I A$ & 5.500 & Atmosfer diş1 & 2018 \\
\hline$S M 3-I I B$ & $>5.500$ & Atmosfer diş1 & 2020 \\
\hline$G M D$ & $>5.500$ & Atmosfer diş1 & 2006 \\
\hline Arrow & $1.000-3.000$ & Atmosfer içi $(40$ km) & 2000 \\
\hline $\begin{array}{l}\text { SAMP-T Aster } \\
\text { Blok } 1\end{array}$ & 600 & Alt katman $(\sim 20 \mathrm{~km})$ & 2010 \\
\hline
\end{tabular}

Alt katman veya terminal safha tabir edilen füze savunma önlemlerinin yetersizliklerini dikkate alan $\mathrm{ABD}$, füze savunmasının üst katmana taşınması için son 20 yıldır yoğun ve çok yüksek bütçeli çalışmalar yürütmüş, bu çalışmalar sonucunda şekillenen atmosfer dı̧̧ında önleme yapabilecek sistemler 2010'lu yıllarda kullanıma girmeye başlamıştır. ABD anakarasını korumaya yönelik GMD bir kenara bırakılacak olursa, bu sistemlerden ilki ve en olgun olanı ABD donanmasına ait bazı savaş gemilerince taşınabilen SM3- $I A$ önleyici füzesidir. ${ }^{60} \mathrm{ABD}$ Donanması'nca uzun yıllardır kullanılan SM (Standard Missile) hava savunma füzeleri ile gemilerde mevcut bu füzelere ait ateşleme tertibatı temel alınarak geliştirilen $S M 3$ çözümü, esas itibariyle atmosferin üst tabakalarına ve oradan da uzaya çıkacak şekilde ilave kademeler ve tahrik gücü kazandırılmış taşıyıcı araç niteliğindeki bir füze ile bu füzenin burnuna yerleştirilmiş minik bir uzay aracından oluşmaktadır. SM3 füzesi firlatıldıktan sonra kendini firlatan geminin gönderdiği yönlendirme komutları doğrultusunda atmosferin üst katmanlarına çıkmakta, uzaya ulaştığında ise kendi kendine

59 ABD, İsrail ve Avrupa ülkelerinin yanı sıra, Rusya Federasyonu ve Çin Halk Cumhuriyeti de balistik füzeleri önleyebilecek sistemler geliştirmiş ve geliştirmeye devam etmektedir. Ancak bunlar genelde, kökeni Sovyetler Birligi'ne uzanan S-300 hava savunma sisteminin balistik füze önleme yeteneği kazandırıldığı ifade edilen türevleridir ve özellikle uzun menzilli balistik füzelere karşı etkinliklerinin ne olacağı henüz açıklık kazanmamıştır. Bkz.: Richard D. Fisher Jr. ve Carlo Kopp, “Game Changers”, Defense Technology International, Aralık 2009, s. 32-34.

60 2011'de SM3 füzesi taşıyan ABD savaş gemisi sayısı 23 olup, 2016'da bu sayının 41'e ulaşması planlanmıştır. Bkz. Ronald O'Rourke, Navy Aegis Ballistic Missile Defense (BMD) Program: Background and Issues for Congress, Congressional Research Service Report for Congress, Washington, D.C, 19 Nisan 2011, s. 12. 
manevra yapabilen, üzerindeki kızılötesi algılayıcısı sayesinde tehdit füzeyi kendisi bulup yok eden bir nevi uzay aracı sayılabilecek $K W$ yi (Kinetic Warhed) serbest burakmaktadır. Angajmanın bundan sonrası yerden herhangi bir müdahale veya desteğe gerek kalmaksızın bu küçük araç tarafindan gerçekleştirilmekte ve uzayda yol alan tehdit füze kinetik temasla, yani "kafa-kafaya çarpışma" (bit-to-kill) yoluyla imha edilmektedir.

Burada sıklıkla gözden kaçan önemli bir detay, SM3'ün taşıdığı füzesavar aracın uzaya mümkün olduğunca erken çıkartılmasının, gelmekte olan tehdit füzenin atmosfere girmeden henüz uzaydayken yakalanabilmesi açısından hayati önem taşıması, buna karşıllk savaş gemisi üzerinde bulunan ve $S M 3$ 'ü yönlendirmesi beklenen arama radarınınsa gelmekte olan balistik füzeyi yeterince erken tespit edememesidir. Bu kritik engeli aşmak için $\mathrm{ABD}$ 'nin geliştirdiği metot, füzenin furlatıldığı bölgeye daha yakın konumdaki ikinci bir füze tespit-takip radarınca derlenen hedef bilgilerinin, ABD'nin balistik füze savunmasına tahsisli $\mathrm{C}^{3}$ ağ 1 üzerinden gerçek zamanlı olarak savaş gemisine aktarılması, bu sayede geminin henüz kendi radar ekranında gözükmeyen balistik füzelere karşı hiç vakit kaybetmeden $S M 3$ füzeleri firlatabilmesidir. Böylece, tehdit oluşturan balistik füze henüz yerden yükselirken onu durduracak önleyici füzenin de yola çıkması sağlanmakta ve ikisinin daha geç bir evrede değil de uzayda buluşabilmesini teminen kritik önemde dakikalar kazanılmaktadır. Bu sayede, hem 3.000 km'ye kadar menzile sahip balistik füzelerin durdurulması imkân dâhiline girmekte, hem de artık sadece nokta hedefleri değil, çok daha geniş coğrafi alanların, hatta ülkelerin korunması mümkün olabilmektedir. ${ }^{61}$

\section{EPAA - 1nci Safha}

Tehdit füzelerin mümkün olduğunca tespit edilip takibe alınmasının taşıdığ 1 önem sebebiyle, ABD'nin EPAA stratejisinin 2011-2015 y1llarını kapsayan 1nci safhasinda Avrupa'ya konuşlandırmayı öngördüğü füze savunmasına yönelik iki unsurdan birincisi, Karadeniz ve Doğu Akdeniz sularında dolaşacak $S M 3-I A$ füzesi taşıyan savaş gemileri, ikinci unsur ise tehdit füzelerin olası firlatma alanları yakınında bulunacak TPY-2 füze tespit ve takip radarlarıdır. ${ }^{62} \mathrm{Bu}$ radarlardan ilki 2008 yılından bu yana İsrail'de görev yapmaktadır. İkinci TPY-2 radarının konuş yer olarak ise 2011'de Kürecik/Malatya'nın belirlenmesiyle, Türkiye'nin en azından EPAA'nın 1nci safhasında en kritik Avrupa ülkesi konumuna yükseldiği söylenebilir. ${ }^{63}$ EPAA'nın 1nci safhasında, menzili 3.000km'ye kadar olan balistik füzelere karşı Avrupa'nın güneydoğusu üzerinde "sınırlı" bir füze savunma kalkanı tesis edilmektedir. Örneğin Doğu Akdeniz’de devriye gezen ve $S M 3-L A$ füzeleri taşıyan bir veya tercihen iki ABD savaş gemisi, Yunanistan'ın batısından İsrail' in doğusu-

61 Sea-Based Missile Defense Flight Test Results in Successful Intercept, ABD Füze Savunma Ajans1 (MDA) Basin Duyurusu, 15 Nisan 2011.

62 Fact Sheet on U.S. Missile Defense Policy: A Phased Adaptive Approach for Missile Defense in Europe, Beyaz Saray Basın Bürosu basın duyurusu, 17 Eylül 2009; O’Reilly, Ballistic Missile Defense Overview, s. 3, 5; O'Rourke, BMD program, s. 3-7; Norman Freidman, "Afloat and ashore: Aegis BMD follows an adaptive course", Jane's Navy International, Eylül 2011, s. 36.

63 Fatih Altaylı, “Kürecik'i vazgeçilmez yapan 5 saniye”, HaberTürk, 24 Mart 2012. 
na dek uzanan coğrafyayı balistik füzelere karşı koruyabilmektedir. Buna karşılık, SM3’ün denizde konuşlu bir sistem olması sebebiyle denizden uzak karasal bölgelere koruma sağlanamadığ1, örneğin Türkiye'nin doğu ve güneydoğusunun SM3 füzelerinin koruma alanı dişında kaldığı anlaşılmaktadır. ${ }^{64}$

\section{EPAA - 2nci Safha}

EPAA stratejisinin 2015-2018 dönemine yönelik 2nci safhasında, SM3-IB adı verilen daha gelişmiş bir önleyici füzenin devreye girmesi ve bu önleyici füzelerin artık sadece ABD savaş gemilerinde değil, Romanya'daki karada konuşlu bir üste hazır bulundurulması öngörülmektedir. $I A$ türevine göre $I B$ önleyici füzesinin getireceği yenilik, mini uzay aracında daha gelişmiş kızılötesi algılayıcı ve daha güçlü tahrik sistemi kullanılması sayesinde hem 3.000 km'nin üzerindeki menzillere sahip balistik füzelere karşı "sınırlı" bir savunma imkânı yaratılması, hem de balistik füzeleri sahte hedef benzeri aldatma önlemlerinden ayırt edebilecek teşhis hassasiyetinin kazanılmasıdır. EPAA'nın 2nci safhasında ilaveten, ABD'nin üst katman ve atmosfer dışı önleme yapması amacıyla geliştirmekte olduğu bir diğer füze savunma sistemi olan mobil ve karada konuşlu THAAD'ın (Terminal High-Altitude Area Defense), SM3'ün koruma sağlayamadığı bölgelere, örneğin doğu ve güneydoğu Anadolu’ya konuşlandırılması planlanmaktadır. ${ }^{65}$

\section{EPAA - 3ncü Safha}

2018-2020 arasında uygulamaya aktarılacağı açıklanan EPAA'ın 3ncü safhasında ise, Romanya'ya ek olarak Polonya'da ikinci bir füze savunma üssünün devreye sokulmas1, ayrıca $S M 3-L A$ ve $I B$ füzelerine kıyasla uzaya $\% 50$ daha hızlı yükselebilecek, bu sayede yaklaşmakta olan balistik füzeleri uçuşlarının daha erken aşamasında, hatta henüz yerden yükselirken yakalayabilecek IIA tipi önleyici füzelerin kullanıma sokulması hedeflenmektedir. 3üncü safhada ayrıca, tehdit oluşturan balistik füzenin henüz yerden yükseldiği aşamada takibini sağlamak üzere, bugüne kadar kullanılan nispeten eski teknolojili DSP (Defense Support Program) uydularının yerini yeni nesil erken ihbar uydularının alması öngörülmektedir. Ayrıca, aynı noktadan salvo, yani gruplar halinde atılan füzeleri birbirinden ayırt etmekte zorlanan TPY-2 radarının bu açı̆̆ını kapatacak şekilde, kızılötesi algılayıcılar taşıyan ve fırlatma bölgesinin yakınına sokulabilen Reaper insansız uçaklarının kullanıma sokulması planlanmaktadır. ${ }^{66}$ Tüm bu yeni yetenekler ve teknolojilerin devreye alınmasıyla, bir yandan füze kalkanınca korunma sağlanan coğrafi alan genişlerken, belki daha mühimi artık $5.500 \mathrm{~km}$ ve üzerindeki menzillere sahip füzelere, yani kıtalararası balistik füzelere karşı da sınırlı bir savunma yeteneği şekillenmeye başlayacaktır. İşte bu noktadan itibaren, 3ncü safhada kazanılacak füzesavar yete-

64 "NATO missile defences in Europe: Shooting down a plan", The Economist, 26 Eylül 2009, s. 63-64.

65 O'Reilly, Ballistic Missile Defense Overview, s. 3-7.

66 Ibid., s. 3-7. 
neğin kendi kıtalararası füzelerine ve dolayısıyla stratejik nükleer caydırıcılığına yönelik bir tehdit oluşturacağından endişe duyan Rusya Federasyonu'nun itiraz, hatta tehditleri ortaya çıkmaktadır.

\section{EPAA - 4ncü Safha}

ABD'nin 2020'den sonra devreye sokulacağını ifade ettiği 4ncü safhayla birlikte, kazanılacak füze savunma imkânlarının niteliği itibariyle ilk üç safhaya kıyasla füze savunmasının bir hayli farklı ve yeni bir boyutuna geçilmesi amaçlanmıştır. Bu kapsamda, 4ncü safhanın merkezinde yer alan ve sifirdan dizayn edilecek yeni bir silah olan IIB önleyici füzesiyle, tehdit oluşturan füzelerin artık balistik yörüngelerinin tepe noktası veya alçalma aşamasına gelmeleri beklenmeden, henüz "yükselme" (ascent) aşamasındayken imha edilmeleri hedeflenmiştir. ${ }^{67} \mathrm{ABD}, 2009$ 'den itibaren füze savunmasındaki önceliğ̈in "erken önleme" (early intercept) doktrini ve bu bağlamda yükselme safhasına yönelik projelerin hayata geçirilmesi olduğunu saklamamaktadır. ${ }^{68}$ Çünkü bu aşamada motoru susmuş ve kazandığı ivmeyle uzaydaki yolculuğuna henüz başlamakta olan balistik füze, eğer birden fazla harp başlığı veya füzesavar sistemleri aldatmaya yönelik (çaf, sahte hedefler vb) karşı önlemler taşıyorsa, henüz bunları bırakmaya firsat bulamadan vurulmuş olmakta, böylece füze savunmasının başarıya ulaşması garantilenmektedir. Yükselme aşamasında önleme girişimlerinin önündeki ilk engel olan yerden yeterince süratli bir şekilde yükselip hedefine ulaşabilecek bir önleyici füzenin bugüne kadar geliştirilememiş olmasının, EPAA'nın 4ncü safhasındaki SM3-IIB programıla aş1labileceği ümit edilmiştir. ${ }^{69}$

EPAA'ın ilk üç safhası çerçevesinde kazanılması hedeflenen yetenekler, öncelikle Avrupa'nın ve bölgedeki diğer ABD müttefiklerinin balistik füze tehdidine karşı korunmasına yönelikken, 4ncü safhanın uygulamaya aktarılmasıyla artık ABD anakarasına yönelik kıtalararası balistik füzelerin henüz Ortadoğu veya Avrupa üzerindeyken vurulmaları imkânı yaratılarak, ABD'nin 1983 yılındaki "Yıldız Savaşları" girişiminden bu yana vazgeçmediği $\mathrm{ABD}$ anakarasının balistik füzelerden korunması hedefine yaklaşılabileceği düşünülmüştür. Ancak, ABD anakarasına ulaşabilecek kapasitedeki kıtalararası balistik füzelerini ABD ile arasında Soğuk Savaş yıllarından bu yana devam eden nükleer dengenin ve nükleer caydırıcılığının ana unsuru olarak gören Rusya Federasyonu'nun, EPAA'nın 4ncü safhasından büyük rahatsızlık duyduğunu söylemeye bile gerek yoktur. Rusya'nın bu olasılığa karşı verdiği tepkiler ve bu durumun TürkiyeRusya ilişkileri üzerindeki yansımaları, EPAA'nın yukarıda özetlenen safhalarının birer

67 "Yükselme safhası”, İngilizce'deki “ascent phase” teriminin karşılığı olarak kullanılmıştır. Yurt dışındaki çeşitli kaynaklarda bu safhada gerçekleşen önleme girişimleri için "EIP - early intercept phase" (erken önleme safhası) terimine de rastlanmaktadır. Ayrıca, bu safhayı "upper-boost" ve "post-boost" gibi kendi içinde kademelendiren kaynaklar da mevcuttur.

68 Doug Richardson, "Boosting missile defence: technologies focus on early interception challenges", Jane's International Defence Review, Ocak 2010, s. 32-33.

69 Turner Brinton, "U.S. Satellites Track Missile in Milestone Test", Defense Nerws, 11 Nisan 2011, s. 22; Jim Hodges, "Wanted: anti-missile details", C4ISR Journal, Nisan 2010, s. 22-23. 
birer devreye girmesiyle Türkiye'nin karşı karşıya kalacağı yeni stratejik denklemlerin sadece birisini teşkil etmektedir.

\section{EPAA'da Etkinlik ve Takvim Belirsizlikleri}

Hatırlanacağı üzere, EPAA'nın 1nci ve 2nci safhalarında ABD'nin Doğu Akdeniz ve Karadeniz'e konuşlandırdığg savaş gemileri ile Romanya'daki bir üste bulunacak SM3 önleyici füzelerinin, yaklaşmakta olan balistik füzelere karşı Türkiye'nin kıyılara yakın bölgeleri üzerinde etkili olabileceği, buna karş1lık denizden uzak konumdaki doğu ve güneydoğu Anadolu'ya korunma sağlanamayacağı anlaşılmaktadır. Türkiye'nin yüzölçümünün kimi analizlere göre 1/3'üne, kimilerine göreyse yaklaşık yarısına karşılık gelen ve içerisinde İran füzelerinin en öncelikli hedefi olduğu varsayılabilecek Kürecik/Malatya'daki ABD radarının da yer aldığı bu ölü bölgenin savunulması için, bir kriz anında ABD ve diğer NATO müttefiklerinin konuşlandıracağı Patriot hava/füze savunma sistemlerinin devreye sokulması öngörülmektedir. ${ }^{70}$ Fakat burada gözden kaçırılmaması gereken çok önemli bir detay Patriot'ların menzili 1.000 km'ye kadar olan balistik füzelere karşı etkili olabildiği, buna karşılık İran'ın olası bir çatışmada kullanabileceği balistik füzelerin menzilinin 2.000 km'nin üzerine çıkabileceği, dolayısıyla en azından önümüzdeki birkaç yıllık süreçte Doğu Anadolu'nun füze tehdidine karşı korunmasız kalacağı gerçeğidir. Bölgeye yönelik balistik füze tehdidinin hedefinde öncelikle Kürecik'teki ABD radarının bulunması, buna karşılık Kürecik radarı sayesinde işlerlik kazanan füze kalkanının bu radara ve ona ev sahipliği yapan bölgeye koruma sağlayamayacak olması önemli bir tezat oluşturmaktadır. $\mathrm{Bu}$ olumsuzluğun giderilebilmesi için ABD'nin orta vadeli çözümü, bir kriz durumunda Doğu Anadolu'nun aralarında bulunduğu korunmasız bölgelere daha gelişmiş THAAD füzesavar sistemlerinin gönderilmesidir. Ama İran'la bir çatışma anında İsrail'in ve Körfez ülkelerindeki ABD askeri tesislerinin korunması için de bel bağlanan sınırlı sayıdaki THAAD sisteminden ne kadarının Türkiye'nin savunmasına tahsis edilebileceği henüz açıklık kazanmamıştır. 2013 itibarıyla ABD'nin envanterine giren THAAD batarya sayısının 4, füze sayısının ise sadece 96'yla sınırlı olması, buna karşılık İran'ın envanterindeki balistik füzelerin sayısının binlerle ifade edilmesi durumu izah etmektedir. ${ }^{71}$ Ayrıca, siyasi otoritenin “Türkiye topraklarına füze değil radar kabul edildiğì” şeklindeki söyleminin de, güneydoğu Anadolu'nun korunabilmesi için THAAD sistemleri konuşlandırılmasının bir zorunluluk olması sebebiyle er ya da geç geçerliliğini yitireceği anlaşılmaktadır. ${ }^{72}$

EPAA'nın gerçek bir füze saldırısı karşısındaki performansına yönelik bir diğer belirsizlik, İran'ın sahip olduğu füzeleri küçük gruplar halinde ve uzun zaman dilimlerine yayarak peyderpey ateşlemek yerine, birkaç düzine hatta birkaç yüz balistik füzeyi

70 Alan B. Hicks, AEGIS Ballistic Missile Defense Overview, Marshall Institute, Washington, D.C, 28 Kasım 2007; Shooting down a plan, s. 63-64; Sonumut, "Füze Kalkanı".

71 Patrick O’Reilly, "Missile Defense - The Way Forward”, Military Technology, Ağustos 2009, s. 37; Hicks, AEGIS Overview.

72 “Füze değil, radar üssü”, Beyaz TV, 19 Eylül 2011, http://www.beyazgazete.com/video/2011/ 09/19/fuze-degil-radar-ussu-beyaztv.html (Erişim tarihi: 30 Kasım 2011). 
yaylım ateş şeklinde aynı anda firlatması halinde savunma sistemlerinin satüre olup olmayacağı, hatta bunun da ötesinde böylesi yoğunlukta bir saldırıyı etkisiz kılacak önleyici füze stoklarına sahip olunup olunamayacağıdır. ${ }^{73}$ EPAA'nın erken safhalarında ABD'nin Avrupa'nın füze savunmasına tahsis etmeyi düşündüğü gemi sayısı en fazla 6, ABD gemilerince taşınan SM3 füzelerinin sayısı ise 100 civarında olup, bu rakama Kuzey Kore ve muhtemelen Çin kaynaklı tehdide karşı Uzakdoğu sularındaki ABD gemilerinde tutulan SM3 füzeleri dâhildir. ${ }^{74} \mathrm{EPAA}$ 'nın 2nci safhası için Romanya'da inşa edilecek füze savunma üssünde ise sadece 24 füze bulunacağı hatırlanacak olursa, onlarca hatta yüzlerce füzenin yer alacağı yaylım ateşi şeklindeki bir saldırı karşısında EPAA'nın etkinliğine ilişkin soru işaretleri belirginleşmektedir. ${ }^{75}$

EPAA'nın sağlayacağı korumanın etkinliği bağlamında sorgulanması gereken üçüncü husus, özellikle 2nci ve 3üncü safhaların öngörülen zaman aralıklarında hayata geçirilip geçirilemeyeceği, 1nci safhayı takip eden aşamalar için geliştirilmesi gerekecek sistemlerin ve yeni yeteneklerin gecikme veya sorun olmadan kullanıma hazır hale gelip gelemeyeceğidir. Bu kapsamda EPAA'nın pürüzsüz ve zamanında uygulamaya aktarılabilmesi öncelikle $S M 3$ programının sorunsuz bir şekilde yürütülebilmesine bağlı olduğu halde, $S M 3$ 'ün $I B$ ve $I L A$ versiyonlarının geliştirme programlarında daha şimdiden bazı gecikme ve sorunlar gözlenmektedir. SM3-IB' nin geliştirme programının her bir atış denemesi arasında 1 yllı bulan boşluklar olduğundan, tam veya kısmi başarısızlıkla sonuçlanan her bir deneme atışı geliştirme takviminde önemli kaymalara sebebiyet verebilmektedir. ${ }^{76}$

SM3 programındaki gecikmelerin yanı sıra, EPAA çerçevesinde tesis edilen kalkanın bir bütün halinde etkin olabilmesi açısından hayati önem taşıyan erken ihbar ayağında da bazı gecikme ve boşluklardan bahsedilmekte, örneğin $D S P$ erken ihbar uydularının yerini alacak uydu programlarındaki gecikmelere dikkat çekilerek, EPAA'in etkinliği için kritik önemdeki yeni nesil uydulara geçişte boşluk ve kesintiler yaşanabileceği uyarısı yapılmaktadır. EPAA'nın 2nci ve takip eden safhalarının hayata geçirilebilmesinin henüz ispatlanmamış ve üzerindeki çalı̧̧malar devam eden teknolojilere bağlı olduğu, bu konuda yaşanacak gecikmelerin EPAA'nın uygulama takvimini etkileyeceği ABD'li yetkililerce de kabul edilmektedir. ${ }^{77}$

73 Daniel Goure, DoD and the Army Have Their Math Wrong On Missile Defense Cuts, 12 Mart 2012, Lexington Institute, http://www.lexingtoninstitute.org/dod-and-the-army-have-theirmath-wrong-on-missile-defense-cuts? $\mathrm{a}=1 \& \mathrm{c}=1171$ (Erişim Tarihi: 14 Mart 2012).

74 O'Rourke, BMD Program, s.13, s.23-24. Lockheed Martin's Latest Aegis Ballistic Missile Defense Upgrades Certified by U.S. Navy, Lockheed Martin basin duyurusu, 18 Nisan 2012, http://markets. on.nytimes.com/research/stocks/news/press_release.asp?docTag=201204181007PR_NEWS_ USPRXPH89670\&feedID=600\&press_symbol=184690 (erişim Tarihi: 19 Nisan 2012).

75 Daniel Wasserbly, "US Joint Staff call for more complete BMD capability",Jane’s Defence Weekly, 4 Nisan 2012, s. 14.

76 “SM-3 failed to hit target during test, says US MDA", Jane’s Defence Weekly, 7 Eylül 2011, s. 6; William Broad \& David Sanger, "Review Cites Flaws in U.S. Antimissile Program", New York Times, 17 Mayss 2010.

77 Amy Butler, “Missile Warning Alert”, Aviation Week E Space Technology, 19 Nisan 2010, s. 35 36; O’Rourke, BMD Program, s. 29. 
EPAA çerçevesinde bazı gözlemcilerce gündeme getirildiği halde, gerek $\mathrm{ABD}$ gerekse NATO yetkililerince doyurucu yanıtların verilmediği ve bugüne kadar da layıkıyla araştırılmadığı anlaşılan bir diğer boyut, balistik füzelerin vurulması sonucu ortaya çıkacak döküntünün akıbeti ve yerde oluşturacağ 1 zararla ilgilidir. Örneğin, 1991'de Irak füzeleri İsrail şehirleri üzerinde Patriot hava savunma sistemlerince vurulduğunda, infilak sonucu oluşan bazıları bir hayli büyük boyuttaki füze parçalarının yere ulaştığ ve yerleşim bölgelerinde hasar ve can kaybına yol açtı̆̆1 görülmüştür. ${ }^{78}$ Aslında, EPAA çerçevesinde önlenmesine çalışılan füzelerin nükleer veya en azından kimyasal başılı taşıma ihtimalinin bulunması ve durdurulmamaları halinde sebebiyet verecekleri büyük yıkımın, döküntü korkusu sebebiyle füzesavar sistemlerin kullanılmaması gibi bir seçeneği tartışma dışı bıraktığ1 rahatlıkla söylenebilir. Ayrıca, $S M 3$ ve THAAD sistemlerince önlemenin atmosferin çok üst tabakalarında ve uzayda kafa-kafaya çarpışma tekniğiyle yapılması sebebiyle, balistik füze parçalarının büyük oranda buharlaşacağı, ortaya çıkabilecek az sayıdaki parçanın ise yere düşerken sürtünme sonucu yanarak yok olacağı öngörüsü yapılmalıdır. $S M 3$ ve THAAD füzelerinden düşecek ilave motorların (booster) görece küçük boyutlu olması sebebiyle, yere ulaştıklarında neden olacakları zararlar da göz ardı edilebilir. Buna karş1lık bugüne kadar tatminkâr şekilde cevaplanmayan husus, balistik füze tarafindan taşınması muhtemel nükleer harp başlı̆ı içerisindeki radyoaktif maddenin önleme anında meydana gelecek infilak sonrasındaki akıbetinin ne olacağı, atmosferin üst tabakalarında geniş bir radyoaktif bulut oluşturarak, yerkürenin önceden kestirilemeyecek bir bölgesine radyoaktif serpinti olarak geri dönüp dönmeyeceğidir. ${ }^{79}$ Özellikle nükleer silahlar konu olduğunda $\mathrm{ABD}$ 'deki füze savunmasından yana çevrelerin sıklıkla dile getirdiği “en kötü isabet hiç isabet kaydetmemekten iyidir" yaklaşımı esasen geçerli ve isabetlidir. Ancak, örneğin İtalya veya Almanya'daki bir NATO tesisine doğru yol almakta olan İran füzesinin Romanya veya Karadeniz üzerinde vurulması sonucu ortaya çıkacak döküntünün Türkiye'ye veya çatışmayla hiç alakası olmayan Ukrayna gibi bir ülkenin topraklarına dökülmesi ihtimalinin ortaya çıkaracağı çapraşık değerlendirme ve tartı̧̧alar yine de göz ards edilmemelidir.

\section{EPAA'da Komuta-Kontrol Belirsizliği}

EPAA çerçevesinde henüz tam manasıyla tanımlanmamış ve hakkında farklı görüşlerin öne sürüldüğü bir diğer konu da, füze saldırısı durumunda bu füzeleri durdurmaya yönelik karar verme ve yetkilendirme süreçlerinin nasıl işleyeceği, başka bir ifadeyle önleyici füzeleri ateşleyecek düğmenin üzerinde hangi ülkenin ve hangi seviyedeki karar vericilerin parmağının bulunacağıdır. ${ }^{80}$

78 Egeli, Balistik Füzeler, s. 34-36.

79 Brooks Tigner, "Ballistic Missile Defence: Launch Control”, Jane’s Defence Weekly, 8 Şubat 2012, s. 27-28.

80 Ibid., s. 24-27. 
Her ne kadar ABD'ne ait EPAA unsurları etrafinda şekillenecek olsa da, Avrupa üzerinde kurulacak füze kalkanı bir NATO girişimi ve yapılanması muamelesi görecek ise, füze saldırısı durumundaki siyasi istişare, karar alma ve yetkilendirme süreçlerinin de NATO'nun bugüne kadarki uygulama ve usulleriyle uyumlu olması gerekecektir. Diğger taraftan, füze savunmasındaki reaksiyon sürelerinin dakikalar, hatta saniyeler ile ölçülmesi, NATO'nun geleneksel karar süreçlerinin devreye sokulması ve uzlaşma yoluyla karar alınarak yetkilendirmenin saldırı başladığında yapılmasına imkân tanımamaktadır. Bu durumda, füze savunmasına yönelik siyasi istişare ve uzdaşma yoluyla karar ve yetkilendirme süreçlerinin çok önceden yapılması, NATO ve esasen ABD askeri unsurlarının ise bir füze saldırısı anında normal karar süreçlerini beklemeden günler, hatta aylar öncesinden belirlenmiş angajman kurallarına bağlı kalmak suretiyle önceden belirlenmiş durumlarda önceden tanımlanmış savunma önlemlerini kendi inisiyatifleriyle devreye sokmaları gerekecektir. ${ }^{81}$ Fakat NATO'nun bu istikamette kapsamlı bir çalışmayı henüz başlatıp başlatmadığı bilinmemekte, detay senaryo ve prosedürlerin tanımlanması bir yana, bu konuda hangi seçeneklere sahip olunduğunun ortaya konmasının dahi zamana ihtiyaç göstereceği NATO yetkililerince ifade edilmektedir. ${ }^{82}$

Avrupa'yı koruması öngörülen NATO füze kalkanının aslında neredeyse tamamıyla ABD tarafindan tahsis edilmiş yetenekler etrafında şekilleniyor olması sebebiyle, bir füze saldırısı anında kritik kararların NATO'nun karmaşık yapılanmalarından ziyade, ABD'nin zaten NATO müttefiklerine ihtiyaç göstermeksizin kendi kendine yeterli bir nitelik arz eden ulusal komuta-kontrol süreçleri çerçevesinde alınması sonucunu doğurabileceği göz ardı edilmemelidir. Uzaydaki erken ihbar uyduları, karada konuşlu füze tespit radarları, bu algılayıcılardan gelen verileri işleyip dağıtan askeri haberleşme altyapısı ve önleme görevini üstlenecek gemiler ile bunların ateşleyeceği önleyici füzeler neredeyse tamamıla ABD'nin mülkiyeti ve kontrolünde olacağına göre, özellikle çok sayıda füzenin önlenmeye çalı̧̧1dığı karmaşık bir füze savunma senaryosunda inisiyatifin ve kontrolün süratle ABD'ye geçeceği, hatta bu inisiyatifin üst seviyelerdeki komuta mercilerinden uzaklaşarak, önleyici füzeler üzerinde doğrudan kontrole sahip, ama nispeten küçük rütbeler taşıyan Amerikalı gemi komutanlarına kayabileceğinden bahsedilmektedir. ${ }^{83}$ Hangi ülke tarafından firlatılan hangi füzelerin İttifak için tehdit oluşturduğunun tespiti, örneğin İttifak üyesi olmayan İsrail gibi bir ülkeye doğru yol alan füzelerin de durdurulup durdurulmayacağı, önleme yapılırken hangi bölgeler ve ülkelerdeki önleyici füzelerin öncelikle devreye sokulacağı, yaylım ateş halinde koruma önceliğinin hangi ülkelere veya hedeflere tanınacağı gibi siyasi sonuçları olabilecek kritik kararların albay veya yarbay rütbesindeki üniformalı personelce alınması ihtimalinin ortaya çıkması, daha şimdiden

81 Ibid, s. 26.

82 Brooks Tigner, ALTBMD tests, s.19; Bill Sweetman, "Tangled Web", Defense Technology International, Aralik 2009, s. 23.

83 Tigner, Launch Control, s. 28-29. O'Rourke, BMD program, s. 20, 24. Pierre Tran, "MBDA to Europe: Pick a Missile Defense Plan”, Defense Nerws, 18 Eylül 2011, s. 20; Robert Wall, "A New Hope", Aviation Week E Space Technology, 4 Ekim 2010, s. 60-61; Amy Svitak ve Robert Wall, "Ballistic Bulwark", Aviation Week E Space Technology, 18/25 Temmuz, 2011, s. 26-27; Philip Ewing, “U.S. Navy’s BMD Fleet Plans Europe Defense”, Defense Nerws, 28 Eylül 2009, s. 25. 
inisiyatifin ABD'ye veya alt seviyedeki karar mercilerine terk edilmesini istemeyen Fransa gibi bazı İttifak üyelerinin itirazlarıyla karşılaşmakta, bu konudaki çekişme ve tartışmaların önümüzdeki dönemde de devam edeceği anlaşılmaktadır. ${ }^{84}$

\section{EPAA'nın Türkiye Açısından Etki ve Yansımaları}

Türkiye'nin uzun yıllardır karşı karşıya bulunduğu ve İran'ın nükleer silah ele geçirme ihtimalinin belirmesiyle birlikte daha da ciddi bir nitelik kazanan balistik füze tehdidi karşısında salt ulusal imkânlarına dayanarak yeterli caydırıcılık ve savunma yeteneklerini kazanmasının zorlukları daha önceki bölümlerde ortaya konmuştu. Bu yönüyle, NATO'nun başta İran olmak üzere Ortadoğu kaynaklı balistik füzeleri İttifak'a yönelmiş bir tehdit olarak değerlendirmesi ve bu tehdidi etkisiz kılacak savunma önlemlerini hayata geçirmeye başlaması Türkiye açısından hiç kuşkusuz olumlu bir gelişmedir. Stratejik açıdan ele alınacak olursa, balistik füze tehdidi karşısında artık NATO'nun ortak savunma mekanizmalarının ve yeteneklerinin devreye gireceği anlamına gelen bu eğilim, Türkiye'nin 1991 ve 2003 yıllarında Irak füzeleri vesilesiyle karşı karşıya kaldığı belirsizlik ve olumsuzlukların tekrar yaşanması ihtimalini tamamen ortadan kaldırmasa da önemli oranda azaltmaktadır. Konuya finansal açıdan yaklaşıldığında ise, içerdiği gelişmiş teknolojiler ve gerektirdiği büyük çaplı bütçeler itibarıyla en azında şu an için Türkiye'nin imkânlarının bir hayli ötesinde olduğu anlaşılan "üst katman” füze savunmasının NATO ve esas itibarılla EPAA yapılanması çerçevesinde ABD'ye havale edilmesi, Türkiye'nin savunmaya ayırabildiği görece kıt kaynaklarda önemli bir tasarruf yapılmasını da mümkün k1labilecektir.

Diğer taraftan, NATO füze kalkanına ve esas itibariyle ABD'nin EPAA mimarisine dâhil olunmasının önümüzdeki döneme yönelik olarak Türk dış politikası ve savunma politikalarında bazı belirsizlik ve ikilemleri de beraberinde getirmekte olduğu gözden kaçırılmamalıdır. Bu kapsamda örneğin, NATO tarafından tesis edilmekte olan füze kalkanının koruması altına girebilmek için Türkiye'nin yapması gereken tek fedakârlı̆̆ın, EPAA çerçevesinde ABD'nin Kürecik'e "tamamen savunma amaçlı" bir radar yerleştirilmesine izin vermekten ibaret olacağ 1 şeklinde siyasi otoritenin en tepesindeki isimlerce de teyit edilen bir algı mevcuttur. ${ }^{85}$ Bu varsayım kısa vade için geçerli olsa bile, EPAA'nın takip eden safhaları incelendiğinde, önümüzdeki yıllarda Türkiye'nin gerek NATO, gerekse ABD ile ilişkileri bağlamında yeni talep ve beklentilerle karşı karşıya kalabileceği anlaşılmaktadır.

84 EPAA'nın komuta-kontrol ve karar süreçlerine ilişkin tartışmalar Türk kamuoyunun da gündemine geldiği halde, karar sürecinin ve kontrolün ABD'nde mi yoksa NATO'da mı olacağından ziyade, Türkiye'nin topraklarına konuşlandırılan kalkan unsurları üzerinde kontrole sahip olup olunmayacağı tartışma konusu yapılmıştır. Bkz.: "Komuta Kontrol Sonraki Aşama", Bugün, 18 Kasım 2010; Cevher İlhan, "Füze Kalkanı Oyunu ve Yanıltması", Yeni Asya, 22 Kasim 2010, http://hurseda.net/Cevher-Ilhan/1471/Fuze-Kalkani-Oyunu-ve-Yaniltmasi-(1). html (Erişim Tarihi: 15 Nisan 2012); Erol Bilbilik, "Lizbon, Yeni NATO ve Nükleer Stratejik Konsepti”, Illk Kurşun, 17 Mart 2011, http://www.ilk-kursun.com/haber/65404 (Erişim Tarihi: 14 Nisan 2012).

85 Beyaz TV, Füze değil radar üssü. 
Örneğin, daha önce EPAA'nın 2nci safhası altında değinildiği üzere, tek bir noktadan grup halinde firlatılmış balistik füzelerin her birinin ayrı ayrı tespit ve takibinde radarlar yetersiz kaldığından, $S M 3$ ve THAAD sistemlerinin etkili olabilmesi için önümüzdeki birkaç yıl içerisinde Reaper insansız uçakları üzerine yerleştirilecek kızılötesi algıllayıcıların devreye sokulması planlanmaktadır. İran kaynaklı füzelerin olası firlatma bölgelerinin 400-500 km yakınına sokulması gerekecek Reaper insansız uçakları için coğrafi açıdan en uygun konuş yeri olarak Türkiye'nin doğu ve güneydoğusundaki meydanlar ön plana çıkmaktadır. ${ }^{86} 2011$ yılının son aylarında ABD'ye ait Predator insansız hava araçlarının PKK'ya karşı istihbarat desteği sağlanması maksadıyla İncirlik'e konuşlandırılması ve bu suretle Türk topraklarının fiilen ABD insansız uçaklarının uçuşlarına açılmış bulunması sadece terörizmle mücadele değil, EPAA bağlamında da not edilmesi gereken bir gelişmedir. ${ }^{87}$ ABD Hava Kuvvetleri daha eski ve düşük performanslı Predator'larını önümüzdeki birkaç yıl içerisinde Reaper'larla değiştirmeyi öngördüğünden, bu değişiklik yapıldığında balistik füze tespit ve takip kapasitesine sahip Reaper insansız hava araçlarının Türkiye topraklarını kullanması durumu zaten kendiliğinden yaratılmış olacaktır. ${ }^{88}$

Ayrıca, şu anda pek değinilmemekle birlikte, EPAA'nın 3ncü safhasından itibaren konuşlandırılacak $S M 3$ türevlerinin yerden yükselme aşamasında bulunan balistik füzeleri yakalayabilmek için muhtemel fırlatma bölgelerinin daha yakınına konuşlandırılmaları ihtiyacı gündeme gelecektir. Bu kapsamda, İran'dan Batı'ya doğru yol alan füzelerin yükselme aşamasında önlenebilmesi için Romanya veya Polonya'nın en uygun konumda bulunmadığı, SM3'lerin yakın bir gelecekte Karadeniz'de seyreden savaş gemilerinde, Kafkaslarda veya Türkiye'deki yeni üslerde konumlanmasının gerekeceği ifade edilmektedir. ${ }^{89}$ $\mathrm{Bu}$ öngörü, Türkiye'nin füze kalkanına katkısının salt savunma amaçlı bir radar üssü ile sınırlı olduğu yönündeki mevcut politika ve söylemlerin geçerliliği konusunda daha önce değinilen soru işaretlerine yenilerini eklemektedir. ${ }^{90}$

İlaveten, EPAA’nın ilerleyen safhalarında ağırlığın Karadeniz'deki deniz unsurlarına kayması ihtimali, Karadeniz'e girebilecek savaş gemisi sayısı ile bu gemilerin Karadeniz'de kalabileceği süreleri sınırlayan Montrö Boğazlar Sözleşmesi’nin göz ardı ya da tadil edilmesi yönündeki baskıları da beraberinde getirebilecektir. ${ }^{91}$ Rusya’nın, üstelik kendi kıtalararası balistik füzeleri için de tehdit oluşturacak $\mathrm{ABD}$ savaş gemilerini kıyılarının hemen açı̆̆ında görmekten duyacağı rahatsızlı̆̆ı ve bu olumsuzluğu engellemek için Montrö Anlaşması hükümlerinin harfiyen uygulaması yönünde Türkiye'ye uygulayacağı baskıyı tahmin etmek hiç de zor değildir.

86 David A. Fulghum, "Past is prologue: aircraft that can intercept ballistic missiles may be in vogue again”, Aviation Week E Space Technology, 20-27 Eylül 2010, s. 72-73.

87 “4 Predator İncirlik'te”, CNN Türk, 15 Kasım 2011, http://www.cnnturk.com/2011/ turkiye/11/15/4.predator.incirlikte/636781.0/index.html (Erişim Tarihi: 20 Aralık 2011).

88 Hodges, Wanted, s.22-23; Amy Butler, "Reaping the Benefits", Aviation Week E' Space Technology, 15 Ağustos 2011 s.48-50.

89 Butler, Reaping Benefits, s.48-50; Amy Butler, "End Game”, Aviation Week E Space Technology, 13 Haziran 2011, s. 40-43.

90 Beyaz TV, Füze değil radar üssü.

91 E. Tuğgeneral Ergün Mengi ile söyleşi, 15 Aralık 2011. 


\section{Rusya ile İlişkiler}

ABD’nin, Avrupa üzerinde bir füze kalkanı kurulması yönündeki girişim ve çalışmalarından en büyük rahatsızlığı duyan ülkelerin başında, kendi kıtalararası balistik füzelerinin ve dolayısıyla $\mathrm{ABD}$ karşısındaki nükleer caydırıcılığının tehdit altına girebileceğinden endişe duyan Rusya Federasyonu gelmektedir. ABD ve NATO tarafindan yürütülen süreçlere Rusya'nın da dâhil edilmesi, hatta füze kalkanında aktif rol almasına yönelik girişim ve görüşmelerden arzu edilen sonuçlar çıkmamı̧tır. ${ }^{92}$ Hatta 2011 sonlarından itibaren bu alandaki NATO-Rusya diyalogunda gerileme kaydedilerek, Rusya’nın NATO'ya ve füze kalkanının Doğu Avrupa ve Türkiye'deki unsurlarına yönelik olarak Soğuk Savaş dönemi söylemlerini anımsatan tehditlerine tanık olunmaya başlanmıştır. ${ }^{93}$

ABD ve NATO'nun Rusyàya önerdiği işbirliği çerçevesi, hem NATO ülkeleri hem Rusya'daki füzesavar sensörlerden gelecek bilgilerin karşıllklı değişimini ve tehdit anında atılacak adımların istişare edilmesini öngörmektedir. ${ }^{94}$ Iş̧birliğinin sadece bilgi değişimi ve istişareler ile sınırlı kalmamasını, bunun ötesinde savunmaya yönelik eylemlerin de coğrafi sınırlara göre NATO ile Rusya arasında paylaştırılması yönündeki Rus talepleri, bazı NATO üyelerinin Rusya'nın sorumluluk sahası içinde kalmaya itirazları nedeniyle kabul görmemiştir. ${ }^{95}$ Belki daha da önemlisi, EPAA sayesinde kazanılacak füzesavar yeteneklerin hiçbir şart altında Rusya Federasyonu'na karşı kullanılmayacağını garanti eden yeni bir uluslararası antlaşmanın imzalanması yönündeki Rusya’nın ön şartını $\mathrm{ABD}$ gündemine almaya bile yanaşmamaktadır. ${ }^{96} \mathrm{Bu}$ görüş ayrılıkları da, Rusya'nın kalkana yönelik şüphelerini ve dolayısıyla ABD ile Rusya arasındaki sürtüşmenin dozunu giderek artırmaktadır.

Tüm bu gelişmeler, EPAA'nın önümüzdeki 10 veya 20 yıllık dönemde $A B D$ ile Rusya arasındaki stratejik dengeler ve bu bağlamda yaşanacak tartışma ve çekişmelerin merkezinde yer alacağına işaret etmektedir. Bu durum, bir taraftan EPAA'nın önemli unsurlarına ev sahipliği yapan, diğer taraftan da Rusya ile yakın siyasi, ekonomik ve özellikle de enerji bağlarının geliştirilmesine büyük önem veren bir ülke olarak Türkiye'nin, füze savunması vesilesiyle ABD ile Rusya arasında yeniden şekillenmekte olan stratejik nükleer silahlara ilişkin rekabetin içine çekilmesi ve iki taraf arasında kalması olasılığını akla getirmektedir. Örneğin, Türkiye'nin doğal gazdan sonra nükleer enerji alanında da kendini Rusyaya bağımlı kılacak seçimler yapmış olmasının bu manada yumuşak bir karın oluş-

92 "Russia Says NATO Missile-Defense Talks at Dead End", Radio Free Europe, 6 Şubat 2012, http://www.rferl.org/content/russia_nato_missile_defense_talks/24474887.html (Erişim Tarihi: 7 Şubat 2012).

93 Brooks Tinger, "Russia ramps up anti-BMD shield rhetoric", Jane's Defence Weekly, 30 Kasim 2011, s. 4; "Moskova'dan kalkan uyarısı", Cumburiyet, 24 Kasım 2011.

94 Brooks Tigner, "NATO finds it hard going on missile defence”, Jane’s Defence Weekly, 14 Ağustos 2011, s. 11.

95 Ibid., s. 11.

96 Daniel Gour, Russia Fires a Shot at U.S. Theater Missile Defense Plan, Lexington Institute, 28 Kasım 2011, http://www.lexingtoninstitute.org/russia-fires-a-shot-at-us-theater-missile-defense-plan?a= 1\&c=1171 (Erişim Tarihi: 29 Kasım 2011). 
turup oluşturmayacağının, bu bağımlılığın ileride Moskova tarafindan bir pazarlık kozu ya da baskı unsuru olarak kullanılıp kullanılamayacağının hesaba katılması gerekmektedir.

\section{İran ve İsrail Boyutları}

İran, Türkiye'nin NATO füze kalkanına dâhil olmasından ve bu kapsamda EPAA'nın önemli bir unsuru olan füze tespit-teşhis-takip radarının Kürecik'e yerleştirilmesinden duyduğu rahatsızlığı saklamamış, hatta İran’a yönelik bir saldırı ya da tehdit durumunda öncelikle bu radarı hedef alacağını ilan etmiştir. ${ }^{97}$ Gerek Türkiye'nin, gerekse İran'ın güneyindeki Körfez ülkelerinin sadece $A B D$ tarafindan sağlanabilen füze savunmasının ve ABD'nin caydırıcı şemsiyesinin altına girmeye başlamaları, nükleer silahlara ilgi duymaya başladığı ilk günden itibaren İran'daki karar vericilerin hesaba katmış olmaları gereken esasen öngörülebilir bir refleks ve karşılıktır. Bu itibarla, İran’ın nükleer silah programı ve onunla doğrudan bağlantılı balistik füze yeteneklerinde radikal bir değişim yaşanmadığ 1 sürece, Türkiye'nin füze kalkanına yönelik politikalarını ve tutumunu değiştirmesi için herhangi bir sebepten de bahsedilemez. Hatta bunun da ötesinde, İran'in nükleer silah eşiğine bu denli yaklaşmış olmasının Basra Körfezi’nden Mısır’a kadar uzanan Ortadoğu coğrafyasında sebep olduğu rahatsızlık ve tehdit algılaması göz önüne alındığında, NATO ve ABD ile füze kalkanı etrafında yaşanmakta olan yakınlaşma ve işbirliğinin, Türkiye'nin İran haricindeki bölge ülkeleriyle ilişkilerinde bir olumsuzluk yaratmayacağı bile söylenebilir.

Diğer yandan, Türkiye'nin geleneksel politikalarından ayrılarak son birkaç yıldır İsrail karşıtı söylem ve tavır benimsemiş olması itibariyle, Kürecik'e yerleştirilen ABD radarının öncelikle İsrail'in füze savunmasına hizmet edeceği yorum ve suçlamaları, Türkiye'nin Ortadoğu ülkeleriyle ilişkileri bütününde pürüz yaratabilecek bir boyuta işaret etmektedir. ${ }^{98}$ Türkiye'deki siyasi otorite bu yöndeki iddiaları şiddetle reddederek, Kürecik'teki radarın NATO amaçları dışında ve İsrail'in korunmasında kullanıldığının belirlenmesi durumunda $\mathrm{ABD}$ ile imzalanmış protokolün derhal feshedileceğini ilan etmiştir. ${ }^{99}$

Kürecik radarının bağlı olduğu NATO'nun ALTBMD yapılanması, ABD'nin küresel düzeydeki tüm füze savunma faaliyetlerinin omurgası niteliğindeki "Komuta Kontrol Savaş Yönetim ve Haberleşme (Command Control Battle Management and Communications - C2BMC) şebekesiyle en azından 2009'dan bu yana tam entegre şekilde çalışmaktadır. Kürecik’teki radarın tespit ettiği balistik füzelere ait veriler bir Türk generalinin de görev yaptığı Ramstein/Almanya'daki merkeze ulaştıktan sonra diğer tüm İttifak üyeleri gibi $\mathrm{ABD}$ ile de paylaşılmaktadır. Bir kez ABD'nin $C 2 B M C$ şebekesine dâhil olduktan sonra

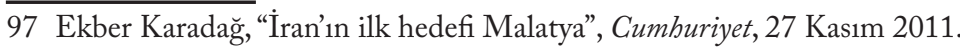

98 Ekber Karabağ, "İran'dan Ankara’ya Suçlama: Füze Kalkanı İsrail'i koruyor”, Cumburiyet, 10 Ekim 2011.

99 Aslı Aydıntaşbaş, "Ankara Füze Kalkanı İstemiyor”, Milliyet, 16 Aralık 2010; "Amacı dışında kullanilamaz", Anadolu Ajansı, 4 Kasim 2011, http://aa.com.tr/tr/alt-manset-haberleri/101362amaci-disinda-kullanilamaz (Erişim Tarihi: 24 Aralık 2011). 
bu verinin $\mathrm{ABD}$ askeri yapılanması içerisindeki hangi kullanıcılarca, hangi coğrafyalarda, hangi amaçlarla kullanıldığının tespiti ve takibi de mümkün değildir. ABD'nin İsrail'in füze savunmasında üstlendiği aktif ve doğrudan rol hesaba katıldığında ve iki ülke arasında bu alanda son 25 yıldır sürdürülen ve ortaklaşa finanse edilen programlar ile karşılıklı veri paylaşımı ve hatta ortak füze savunma tatbikatları göz önüne alındığında, Kürecik radarının elde ettiği verilerin İsrail'in veya başka bir ülkenin savunmasında kullanılmayacağını ummak mantıklı değildir, bu yöndeki iddia ve beyanlar da gerçeği yansıtmamaktadır. Nitekim ABD'li yetkililer, Kürecik'le birlikte dünyanın her tarafındaki sensörlerden gelen verilerin ABD'nin küresel taktik resmine dâhil edildiğini, bu taktik resmin İsrail dâhil diğer ülkelerin savunulmasında kullanılacağını gizlememektedir. ${ }^{100}$

\section{Avrupa mi, ABD mi?}

Daha önceki başlıklar altında değinildiği üzere, EPAA çerçevesinde NATO'nun Avrupalı üyelerinin önüne konan ve fazla seçenekleri olmadığı için kabul etmek durumunda kaldıkları füze savunma kalkanı, esas itibariyle ABD'nin NATO'ya tahsis ettiği sistemler, teknolojiler ve destekleyici altyapı etrafında şekillenmektedir. Bu itibarla, ABD'nin imkân ve yeteneklerinin NATO füze kalkanına eklenmesinden ziyade, NATO ve Avrupa'nın kendi kendine yeterli $\mathrm{ABD}$ füze kalkanının bir uzantısı konumuna indirgendiği ve iplerin büyük oranda ABD'nin elinde olacağı bazı Avrupa ülkelerinin hiç de hoşuna gitmeyen bir durum ortaya çıkmaktadır. ${ }^{101}$

Özelikle Fransa, füze savunması alanındaki tüm teknolojik ve endüstriyel yeteneklerin ABD tekeline girmesinden rahatsılık duymakta, ABD'nin GMD, SM3 ve THAAD sistemleriyle elde ettiği atmosfer dışı önleme yeteneğinin, Avrupa ülkelerinin ortaklaşa yürütecekleri bir proje ile 2020 yılına kadar kazanılması gerektiği görüşünü savunmaktadır. ${ }^{102} 2010$ 'da Fransa ile İtalya'nın envanterlerine girmeye başlayan ve $600 \mathrm{~km}$ menzilli balistik füzelere karşı etkili Aster hava savunma sisteminin yeni geliştirilecek $1 N T$ versiyonu ile $1.000 \mathrm{~km}$ menzilli füzeler, daha kökten değişiklikler içerecek Blok-2 türeviyle de $3.000 \mathrm{~km}$ menzilli balistik füzelerin önlenebileceği anlaş1lmaktadır. ${ }^{103}$ Fransa ayrıca, şu anda sadece ABD'nin sahip olduğu füze tespit amaçlı uydular ile uzun menzilli radarların Avrupa tarafından da geliştirilmesine yönelik planlama ve "kısıtlı" kaynak tahsisini başlatmıştır. Dolayısıyla, Avrupa'nın önümüzdeki 5 veya 10 yillık dönemde en azından $1.000 \mathrm{~km}$ menzilli füzelerin durdurulmasına imkân tanıyacak teknolojik ve operasyonel yetenekleri kazanması beklenmelidir. Buna karşı1ık, geliştirme maliyetlerinin 7,5 milyar Avroyu bulabileceği ifade edilen Aster Blok-2 füzesi, dolayısıyla uzun menzilli balistik füzelerin önlenmesine yönelik yete-

100 "U.S. Maintains Full Control of Turkish-Based Radar”, Defense Nerws, 30 Ocak 2012; Marvin Leibstone, "International Cooperation \& Missile Defence Program", Military Technology, 8/2009, s. 46; O’Reilly, Way forward, s.38; “ABD'den kalkan itirafi”, Hürriyet, 17 Eylül 2011.

101 Duncan Lennox, "Manoeuvres over Missile Defence”, Jane’s Defence Weekly, 9 Haziran 2010, s. 46 102 Butler, Missing Link, s. 23-24.

103 “SAMP/T satıhtan havaya füze sistemi”, Savunma ve Havacılık, No:138, s. 66-76. 
neklerin kazanılmasının, Avrupa'nın içerisinde bulunduğu finansal durum itibarıyla hiç de kolay ve çabuk olmayacağ 1 söylenebilir. ${ }^{104}$

NATO ve ABD ile ittifak ilişkilerinin yürütülmesinde tercihini geleneksel olarak ABD ile ikili ilişkilerden ziyade NATO'nun sunduğu çok taraflı ittifak bağları lehinde kullanmış olan Türkiye'nin, füze kalkanı söz konusu olduğunda da inisiyatifin ve kontrolün sadece teoride değil gerçekte de NATO uhdesinde bulunacağı bir çerçeveyi tercih edeceği varsayılabilir. Bu tercihin bir uzantısı olarak Türkiye'nin, Avrupa ülkelerince tartışılmakta veya yürütülmekte olan füze savunma programlarına ilgi göstermesi, hatta aktif olarak katılmaya çalışması beklenebileceği halde, bugüne kadar bunun gerçekleşmediği ve Türkiye'nin EPAA kapsamında kendisine ABD tarafından sunulan yapıyı aynen kabule meylettiği görüntüsü ortaya çıkmaktadır. Örneğin, yeni bir hava ve füze savunma sistemi satın alınması maksadıyla açılmış bulunan LORAMIDS ihalesinde Avrupalı firmalarca getirilen teklifin fazla ciddiye alınmadığı, geleceğe yönelik füzesavar teknoloji ve çözümlerinin birlikte finanse edilerek ortaklaşa geliştirilmesine yönelik programlara da ilgi gösterilmediği görüntüsü ortaya çıkmaktadır. ${ }^{105}$ Benzer biri duruma, Avrupa menşeli hava/füze savunma sistemleri yerine, ABD kaynaklı SM2/SM3 sistemlerinin ön plana çıktığ Türk donanmasının yeni nesil savaş gemisi projelerinde de rastlanmaktadır. ${ }^{106}$

Türkiye açısından sadece EPAA'nın tanımladığ çerçeveye ve ittifak ilişkilerinde $\mathrm{ABD}$ unsurunu ön plana çıkartacak bir füze savunma yol haritasına bağlı kalınmasının önümüzdeki yıllarda Türkiye'yi yeni talep ve beklentilerle karşı karşıya bırakabileceği, bu bağlamda Türkiye'nin örneğin ABD-Rusya stratejik nükleer rekabetinin veya Ortadoğu'daki tasvip etmediği çatışmaların içine çekilmesi tehlikesiyle karşı karşıya kalabileceği göz ardı edilmemelidir. Dolayısıyla Türkiye'nin, füze savunmasına yönelik politika ve yönelimlerinde çok taraflı ittifak ilişkilerinin önemini ve ağırlığını artıracak seçenek ve girişimlere daha yakın ilgi göstermesi ve destek vermesi isabetli olacaktır.

104 Pierre Tran, "MBDA to Europe: Pick a Missile Defense Plan”, Defense Nerws, 19 Eylül 2011, s. 20; Wall, New Hope, s.60-61; Switak ve Wall, Ballistic Bullwark, s. 26-27.

105 Sünnetçi,Lizbon Zirvesi, s. 154; “Kürecik radarının şifreleri”, Hürriyet, 22 Mart 2012; Ümit Enginsoy, "Turkey in Talks for missile defense system buy", Turkish Daily Nerws, 29 Nisan 2008; "Türkiye geç kalan milli kalkanını nihayet kuracak!", Gazeteci TV, 7 Aralık 2011, http://gazeteci.tv/turkiye-geckalan-milli-kalkanini-nihayet-kuracak-134495h.htm (Erişim Tarihi: 22 Nisan 2012).

106 "Raytheon: İhtiyacı Karşılamaya Hazırız", Savunma ve Havacılı, Cilt: 25, Sayı: 145, 2011/03, s. 59. 


\section{Summary}

Concerns emanating from the inexorable link between Iran's growing ballistic missile inventory and it ambitions to acquire nuclear weapons capability are at the heart of recent US and NATO efforts to constitute a ballistic missile defense shield. Several of Turkey's neighbors possess ballistic missiles, and Turkey has come under the threat of ballistic missile strikes few times in the recent past. Yet, Turkey has not acquired its national missile defense capabilities and opted instead to rely on security guarantees and defensive means provided by US and NATO. EPAA (European Phased Adaptive Approach) pushed on the table by US in 2010 and endorsed by most NATO states is in harmony with Turkey's traditional positioning in the face of missile threat. Thence, not only Turkey has endorsed EPAA, but it has also become a pivotal ally in its implementation. Meanwhile, EPAA is structured almost entirely on military assets and technological resources made available by US, meaning NATO's European allies would have limited contribution and limited control over the course of a conflict involving ballistic missiles. Besides, there are technological, operational, timeline and political/strategic ambiguities surrounding EPAA, especially the later phases of it. From Turkey's perspective, emergence of a threat perception on the part of NATO in relation with ballistic missile inventories in Turkey's vicinity, and implementation of defensive measures to counter that threat is a positive development. Additionally, handing over the task of missile defense to NATO and US would enable Turkey to allocate its limited defense funds elsewhere. On the negative side, during the upcoming phases of EPAA Turkey should not underestimate the possibility of new requests and even fait-accomplis imposed upon herself, and Ankara should carefully consider possible ramifications of those on her relations with Russia, as well as her traditional policy line of observing a balance between US and European elements of her overall relationship with the West. 